\title{
Apatite Glass-Ceramics: A Review
}

\author{
Tomas Duminis*, Saroash Shahid and Robert Graham Hill
}

Unit of Dental Physical Sciences of the Centre for Oral Growth and Development, Institute of Dentistry, Barts and the London School of Medicine and Dentistry, Queen Mary University of London, London, UK

This article is a review of the published literature on apatite glass-ceramics (GCs). Topics covered include crystallization mechanisms of the various families of apatite GCs and an update on research and development on apatite GCs for applications in orthopedics, dentistry, optoelectronics, and nuclear waste management. Most apatite GCs crystallize through a homogenous nucleation and crystallization mechanism, which is aided by a prior liquid-liquid phase separation. Careful control of the base glass composition and heat-treatment conditions, which determine the nature and morphology of the crystal phases in the GC can produce GC materials with exceptional thermal, mechanical, optical, and biological properties. The GCs reviewed for orthopedic applications exhibit suitable mechanical properties and can chemically bond to bone and stimulate its regeneration. The most commercially successful apatite GCs are those developed for dental

OPEN ACCESS

Edited by: Joachim Deubener, Clausthal University of Technology, Germany

Reviewed by: Ana Candida Martins Rodrigues, Federal University of São Carlos,

Brazil

Maziar Montazerian Federal University of São Carlos, Brazil

${ }^{*}$ Correspondence: Tomas Duminis t.duminis@qmul.ac.uk

Specialty section: This article was submitted to Glass Science, a section of the journal

Frontiers in Materials

Received: 18 June 2016 Accepted: 15 December 2016 Published: 09 January 2017

Citation: Duminis T, Shahid S and Hill RG (2017) Apatite Glass-Ceramics:

A Review.

Front. Mater. 3:59. doi: 10.3389/fmats.2016.00059 veneering. These materials exhibit excellent translucency and clinical esthetics and mimic the natural tooth mineral. Due to the ease of solid solution of the apatite lattice, rare earth doped apatite GCs are discussed for potential applications in optoelectronics and nuclear waste management. One of the drawbacks of the commercial apatite GCs used in orthopedics is the lack of resorbability; therefore, the review provides a direction for future research in the field.

Keywords: apatite, glass, glass-ceramic, biomaterial, fluorapatite, chlorapatite, nucleation and crystallization, orthopedic

\section{INTRODUCTION}

Apatite is named after the Greek word "apát" meaning deceit because, in appearance, apatite is often mistaken for a number other minerals. Apatite has a chemical formula $\mathrm{Ca}_{5}\left(\mathrm{PO}_{4}\right)_{3}(\mathrm{~F}, \mathrm{Cl}, \mathrm{OH})$. Due to an adaptive framework structure of apatite (White et al., 2005), its lattice can readily accommodate a number of ionic substitutions. Naturally occurring apatites are found in igneous, metamorphic, and sedimentary earth rocks and relatively recently, versions of fluor- and hydroxyapatite (HAp) were found on the surface of the Moon (McCubbin et al., 2010). Additionally, meteorites from the planet Mars, for example, Chassigny, which fell in provincial France in 1815, brought melt inclusions of Martian fluor- and chlorapatites (McCubbin and Nekvasil, 2008). Apatite is also the major inorganic component naturally found in the hard tissues of vertebrates; therefore, it has a profound biological and clinical significance.

Biological apatites have a chemical formula of $\mathrm{Ca}_{5}\left(\mathrm{PO}_{4}\right)_{3}(\mathrm{OH})$, with some degree of $\mathrm{CO}_{3}^{2-}$ substitution for $\mathrm{PO}_{4}^{3-}, \mathrm{F}^{-}$for $\mathrm{OH}^{-}$, and $\mathrm{Na}^{+}$or $\mathrm{Mg}^{2+}$ for $\mathrm{Ca}^{2+}$ ions. Synthetic HAp has been used in various forms of health care, such as for bone replacement, dental cements, and dental porcelains. However, sintered porous or even dense HAp bone implants often fail due to poor mechanical properties that are inferior to the mechanical properties of the human bone (Table 1). Moreover, sintered blocks of 
TABLE 1 | Mechanical properties of the glass-ceramics for orthopedic applications.

\begin{tabular}{|c|c|c|c|c|c|c|c|c|}
\hline Material & Phase & Density $\left(\mathrm{g} / \mathrm{cm}^{3}\right)$ & $\begin{array}{l}\text { Thermal } \\
\text { expansion } \\
\text { coefficient } \\
\left(\times 10^{-6} K^{-1}\right)\end{array}$ & $\begin{array}{l}\text { Compressive } \\
\text { strength (MPa) }\end{array}$ & $\begin{array}{c}\text { Flexural } \\
\text { strenght (MPa) }\end{array}$ & $\begin{array}{c}\text { Young's } \\
\text { modulus (GPa) }\end{array}$ & $\begin{array}{l}\text { Fracture } \\
\text { toughness } \\
\left(\mathrm{MPa} \sqrt{ } \mathrm{m}^{2}\right)\end{array}$ & Reference \\
\hline $\begin{array}{l}\text { Cortical } \\
\text { bone }\end{array}$ & $\begin{array}{l}\text { Hydroxyapatite } \\
\text { (HAp) + organic } \\
\text { matrix }\end{array}$ & 1.9 & $27.5 \pm 3.9$ & $133-295$ & $35-283$ & $7-20$ & $5-7$ & $\begin{array}{l}\text { An and Draughn } \\
(2000) \\
\text { Ranu (1987) }\end{array}$ \\
\hline $\mathrm{HA}$ & $\mathrm{HAp}$ & 3.16 & 10 & $120-150$ & $60-120$ & $35-120$ & $0.8-1.2$ & $\begin{array}{l}\text { Orlovskii et al. } \\
\text { (2002) }\end{array}$ \\
\hline$A-W$ & $\begin{array}{l}\text { Fluor/oxyapatite and } \\
\text { wollastonite }\end{array}$ & 3.07 & $8-10$ & 1,080 & 215 & 118 & 2 & Kokubo (2008) \\
\hline Bioverit I & $\begin{array}{l}\text { Apatite and } \\
\text { fluorphlogopite }\end{array}$ & 2.8 & $8-12$ & 500 & $140-180$ & $70-88$ & $1.2-2.1$ & $\begin{array}{l}\text { Höland and Beall } \\
\text { (2012) }\end{array}$ \\
\hline Bioverit II & $\begin{array}{l}\text { Apatite and } \\
\text { fluorphlogopite }\end{array}$ & 2.5 & $8-12$ & 450 & $90-140$ & 70 & $1.2-1.8$ & $\begin{array}{l}\text { Höland and Beall } \\
\text { (2012) }\end{array}$ \\
\hline $\begin{array}{l}\text { Bioverit } \\
\text { III }\end{array}$ & $\begin{array}{l}\text { Fluorapatite (FAp) } \\
\text { and aluminum } \\
\text { phosphate }\end{array}$ & $2.7-2.9$ & 14-18 & - & $60-90$ & 45 & 0.6 & $\begin{array}{l}\text { Höland and Beall } \\
\text { (2012) }\end{array}$ \\
\hline $\mathrm{A}-\mathrm{M}$ & FAp and mullite & $2.7-3.3$ & $8-10$ & - & $90-330$ & 70-90 & $1.0-3.3$ & $\begin{array}{l}\text { Ducheyne et al. } \\
\text { (2011) }\end{array}$ \\
\hline
\end{tabular}

HAp require machining to shape to match the complex contours of the defect using expensive diamond tipped tools. A porous and bioactive 3D material may be highly desirable for bone regeneration because a porous material will allow osteoblasts to proliferate and integrate inside the $3 \mathrm{D}$ structure and enable vascularization of the newly formed bone, provided the porosity of the material is adequate. However, with the introduction of porosity into any bone substitute material or implant, mechanical properties are compromised as discussed by Karageorgiou and Kaplan (2005), rendering many of the porous bone substitute materials inappropriate for load-bearing applications.

Since the early 1970s, a number of melt-derived glass-ceramics have been developed that crystallize to apatite phases on controlled heat treatment. A glass-ceramic material can be cast into complex shapes by the "lost wax" casting route, which is usually a simple and cost-effective process. For illustration purposes, the reader is presented with an apatite-mullite glass-ceramic chess piece (Figure 1) produced by casting molten glass to shape by the "lost wax" method, which shows the complexity of shapes and surface detail that can be attained by this route. Machinable glass-ceramics (GCs), such as mica GCs discussed in this review can also be processed by computer-aided design/computer aided manufacturing (CAD/CAM).

Apatite-containing GCs are highly biocompatible and can induce bone formation in vivo (Ducheyne et al., 2011). Therefore, apatite-based GCs are highly attractive for medical and dental applications. A bioactive material is defined as a material that exhibits a biological response at the interface once in contact with a biological tissue. A bioactive material may induce a biological response through its surface topography or by a controlled release of therapeutic ions. A number of bioactive apatite-containing glass-ceramics have been developed for orthopedic applications, and these can be categorized based on the type of secondary crystal phases present in the GC; apatite-wollastonite (A-W), commercially known as Cerabone ${ }^{\circledR}$; apatite-fluoromica (A-FM),

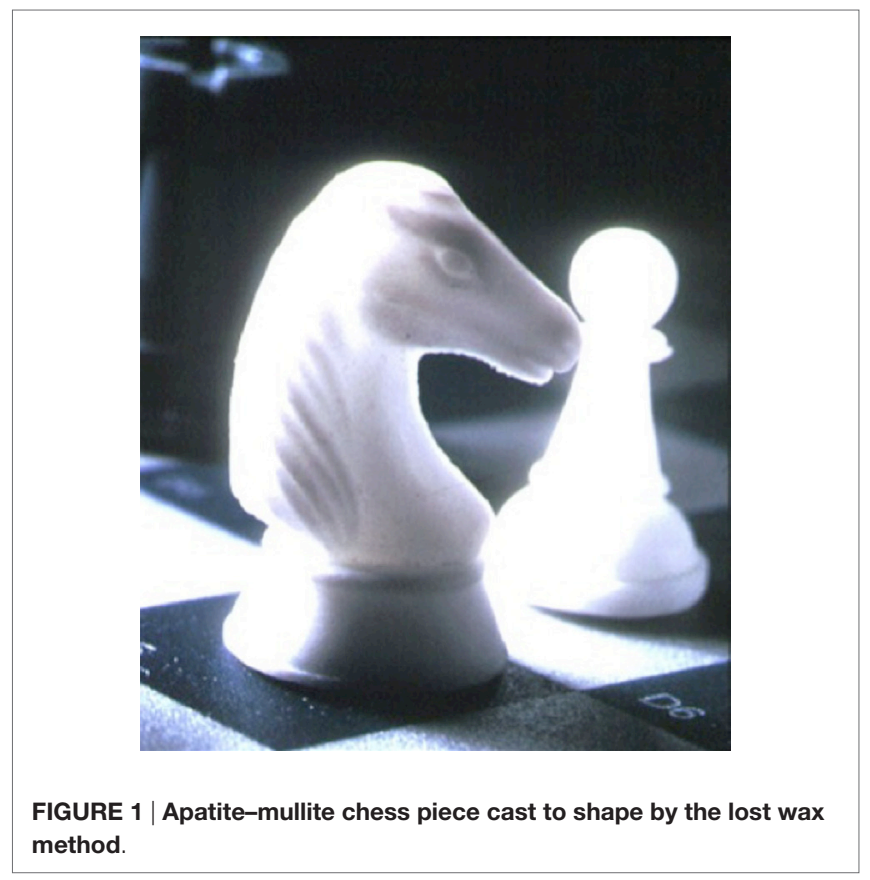

commercially known as Bioverit ${ }^{\circledR}$; and apatite-mullite (A-M). Several apatite-containing GCs have also been developed for restorative dentistry applications for the fabrication of dental inlays, crowns, bridges, and veneers. These are namely apatiteleucite (A-L), commercially known as IPS d.SIGN ${ }^{\circledR}$; and with apatite as the only phase, for example IPS e.max ZirPress ${ }^{\circledR}$ and IPS e.max Ceram ${ }^{\circledR}$.

Apatite is a good host crystal phase for rare earth elements and exhibits low phonon energies (particularly FAp); therefore, apatite-containing glass-ceramics have also been investigated for potential applications in optoelectronics. Apatite phases are also 
particularly attractive in nuclear waste immobilization, such as for the immobilization of $\mathrm{Cl}$ and $\mathrm{Sr}$ isotopes, where these radioactive elements can be readily incorporated into the apatite lattice.

A review on the history and trends of the bioactive glassceramics, including those that do not contain apatite phases has been recently published (Montazerian and Zanotto, 2016). The scope of this article is to review the fundamentals of the structure-property relationship and crystallization mechanisms of the various apatite glass-ceramics used in health care as well as those for potential applications in optoelectronics and nuclear waste management.

\section{PRIOR LIQUID-LIQUID PHASE SEPARATION (LLPS) - PRECURSOR TO NUCLEATION AND CRYSTAL GROWTH}

Liquid-liquid phase separation, also known as amorphous phase separation (APS), can occur in undercooled liquids either at or below the glass liquidus temperature. If LLPS occurs above the glass liquidus temperature, then such phase separation is termed stable immiscibility. On the other hand, if LLPS occurs below the liquidus state, such LLPS is termed metastable immiscibility. Undercooled liquids can undergo phase separation through spinodal decomposition or via nucleation and growth processes (binodal decomposition) (Figure 2).

Spinodal decomposition is a diffusion driven mechanism with no activation energy barrier. A system that undergoes spinodal decomposition is always unstable. In contrast, phase separation by nucleation and growth (in the binodal region) has a large free energy barrier and it is a metastable process involving an activation energy. Small angle neutron scattering (SANS) techniques can be used to study LLPS in both spinodally and binodally decomposed glasses. SANS scattering at lower $q$ values correspond to larger phases, which can be attributed to a phase separation under the binodal region of the phase diagram, whereas neutrons scattered at higher $q$ values correspond to a finer scale phase separation,

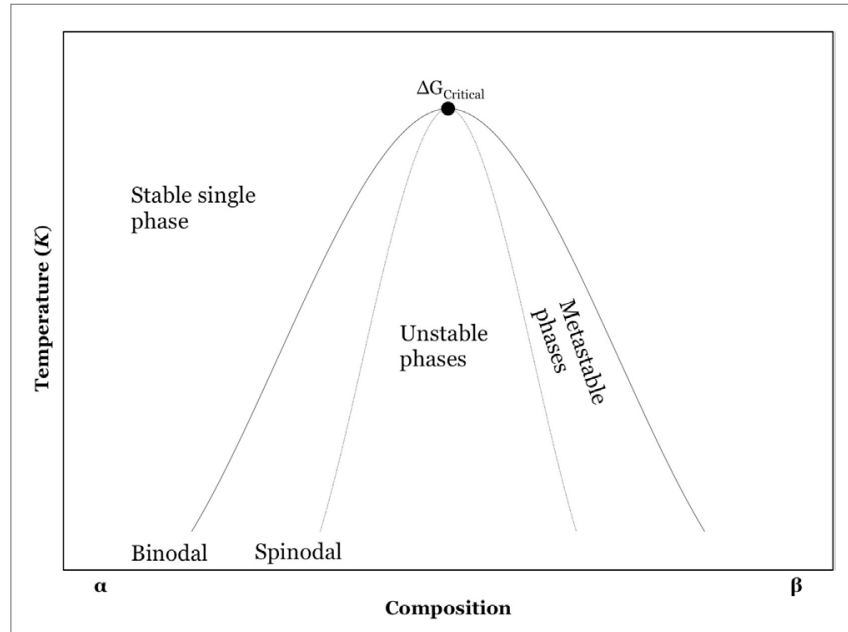

FIGURE 2 | Phase diagram of a binary system. which may be attributed to spinodally decomposed structures (Hill et al., 2007). Spinodal decomposition, unlike nucleation, generally results in sharp scattering maximum often referred to as a "spinodal ring" particularly during the early stages of phase separation. Spinodal decomposition is difficult to observe by microscopy techniques because of the diffuse interfaces between the phases. In contrast, nucleated amorphous phases can be readily observed by microscopy. Transmission electron microscopy (TEM) analysis shows (Hill and Wood, 1995) that LLPS via nucleation and growth results in sharp boundaries between the phases as observed in Figure 3.

Most of the glass-ceramics discussed in this review undergo a bulk nucleation and crystallization, which has been attributed to prior LLPS. Crystal nucleation may be aided by the composition of one of the phases being closer to the crystal phase than the parent glass composition. Figure 3 shows a droplet-like phase that is rich in calcium and phosphorus that crystallizes to fluorapatite (FAp) (Hill and Wood, 1995). However, the A-W GC exhibits surface crystallization of both phases without the occurrence of prior LLPS (Kokubo et al., 1982).

There are two main ideas of how prior LLPS can influence the subsequent crystallization. Vogel and Gerth (1962) proposed that the effect of prior LLPS on glass crytsallization is due to the existence of interfaces in a phase-separated glass, which provide internal surfaces for heterogenous nucleation. However, Cahn (1969) and James (1981) suggested that if the composition of the LLPS phase is close to the composition of the subsequent crystal phase, the activation energy is lowered and subsequent homogenous crystallization is favored.

There are few studies on the importance of LLPS in regard to glass-ceramics, and it is worth briefly reviewing these studies. Ramsden and James (1984a,b) found that quenched $\mathrm{BaO}-\mathrm{SiO}_{2}$ glasses in which LLPS developed simultaneously with the nucleation of the crystals, the crystal nucleation rate increased with isothermal heat-treatment time. Ramsden and James (1984b)

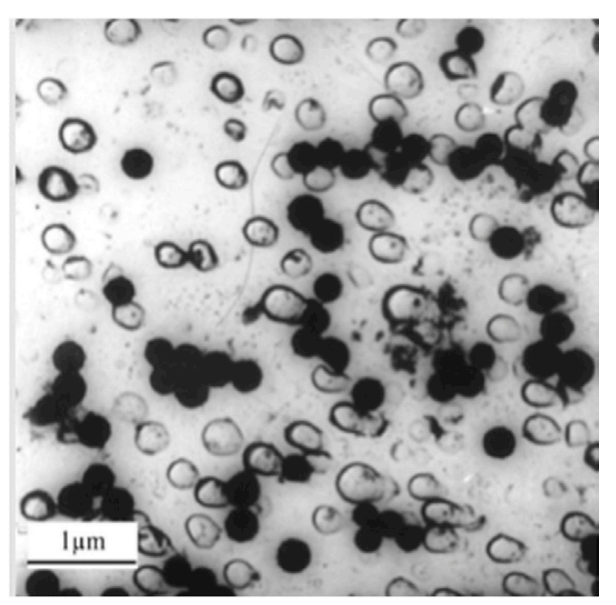

FIGURE 3 | Carbon replica transmission electron micrograph of a fluorapatite-mullite glass-ceramic showing evidence of droplet-like amorphous phase separation giving rise to hexagonal fluorapatite crystals (black zones) (Hill and Wood, 1995) 
reported that the same system without prior LLPS did not show any increases in crystal nucleation rates. Thus, Ramsden and James (1984a,b) and later Zanotto et al. (1986) concluded that the predominant effect on crystal nucleation arises from the compositional changes brought about by phase separation. Although it has been shown that LLPS has a profound role in the formation of simple glass-ceramics, its effect in complex multicomponent systems, such as those with strong nucleants should not be generalized.

Tomozawa (1972) reported that lithium silicate glasses showed considerably increased crystal nucleation rates when the glass had undergone LLPS and proposed that the LLPS droplets consist of silica-depleted diffusion zones at their interfaces, therefore giving rise to sites for heterogenous nucleation.

The mechanism by which LLPS enhances subsequent crystallization depends on the composition of the glass and the composition of the crystalline phase. Apatite GC systems developed by Hill et al. (2004) bulk nucleate via prior amorphous separation, but can also crystallize through a surface mechanism. In simple glasses such as the lithium silicate glasses, LLPS enhances nucleation rate, by reducing the activation energy for nucleation. Although LLPS can enhance subsequent crystallization of a glass, based on the classical nucleation theory, the LLPS droplet diameter (D) should be larger than the critical radius $\left(r^{*}\right)$ for crystal nucleation in order for nucleation to take place within the droplet phase. Therefore, fine scale LLPS can potentially suppress nucleation and subsequent crystallization.

In a study by Clifford et al. (2001a), it was found that base glasses in the A-M systems with a molar Ca to $\mathrm{P}$ ratio of 1.67 (glasses with an apatite stoichiometry) crystallize through an internal or bulk mechanism, and that base glasses with $\mathrm{Ca}$ to $\mathrm{P}$ ratios higher or lower than 1.67 crystallize through a surface mechanism. Interestingly, Clifford et al. (2001a) note that compositions with a molar Ca to P ratio above or below 1.67 can crystallize in bulk following an annealing hold for $1 \mathrm{~h}$ just above the glass transition temperature. Clifford et al. (2001a) study provides evidence that LLPS in the apatite-mullite system can be produced below the liquidus by nucleation and growth.

Rafferty et al. (2000b, 2003) used high temperature dynamic mechanical thermal analysis (DMTA) to show the presence of two mechanical loss peaks ( $\tan \delta$ ) and two reductions in the storage modulus ( $\mathrm{E}^{\prime}$ ) corresponding to two glass transition temperatures (Figure 4) for many of the A-M glass compositions providing evidence of an LLPS. On crystallization of FAp, only one glass transition temperature $\left(T_{\mathrm{g}}\right)$ was observed indicating that one of the two amorphous phases had crystallized to FAp.

Crystals or LLPS droplets in an undercooled liquid can undergo Ostwald ripening (OR) during a heat treatment. During an OR process, crystals or LLPS droplets can grow and produce larger LLPS droplets or crystals. Thermodynamically, OR is a favorable process because larger particles exhibit lower surface energy in contrast to smaller particles. Apatite crystal growth through OR process is observed in apatite glass-ceramics, such as reported by Höland et al. (2015). One of the key characteristics of an OR process is the reduction in the number of droplets/ crystals and an increase in volume as a function of time, pressure or temperature.
Fluorapatite is part of the hexagonal group of crystals; therefore, it exhibits a kinetically favored growth in the crystallographic $c$-direction, which is seen in Höland et al. (2015)'s findings, whereby crystal length as a function of time due to OR process was more pronounced as opposed to crystal expansion at crystallographic $a$-direction. OR process can be used to produce a highly homogenous and mechanically superior microstructure of a GC.

\section{BIOMEDICAL APPLICATIONS OF APATITE GLASS-CERAMICS}

\section{Orthopedics}

\section{Fluor/Oxyapatite-Wollastonite Glass-Ceramics}

Kokubo et al. (1982) developed apatite-wollastonite (A-W) $\left(\beta-\mathrm{CaSiO}_{3}\right)$ system based on $\mathrm{SiO}_{2}-\mathrm{P}_{2} \mathrm{O}_{5}-\mathrm{CaO}-\mathrm{MgO}-\mathrm{CaF}_{2}$, also known by its commercial name Cerabone ${ }^{\circledR}$. The $\beta$-wollastonite phase in the A-W system enhances mechanical performance of the glass-ceramic (Table 1). Kokubo et al. (1987) reported on the A-W GC ability to resist failure by fatigue. It was estimated that the life-time of an A-W GC, under a constant loading of $65 \mathrm{MPa}$ in simulated body fluid is 10 years, compared to a sintered HAp, which under the same loading can sustain the loading before fracture for only $1 \mathrm{~min}$. Both, apatite and $\beta$-wollastonite phases in the A-W system crystallize through a surface mechanism (Kokubo et al., 1982). As such, the A-W GC cannot be cast to shape by the "lost wax" technique and is processed through powder sintering route.

It was often claimed that the apatite phase in the A-W systems is FAp; however, Clifford and Hill (1996) noted that the A-W glasses are very deficient in fluorine content with regard to the FAp stoichiometry. Clifford and Hill (1996) further suggested that the apatite formed in A-W systems is therefore more likely to be a mixture of fluor- and oxyapatite. Based on the pioneering electron spin resonance (ESP) studies on fluor/oxyapatites, it has been long known that $\mathrm{O}^{-}$can occupy $\mathrm{F}^{-}$sites (Segall et al., 1962; Piper et al., 1965). Nonetheless, at present, the availability of high-resolution solid-state characterization techniques such as ${ }^{17} \mathrm{O}$ MAS-NMR coupled with dynamic nuclear polarization (DNP) and high field ${ }^{19} \mathrm{~F}$ MAS-NMR could provide fast and accurate elucidation of oxygen and fluorine environments in the A-W GC; however, such work is yet to be published.

Calver et al. (2004) reported that modified Kokubo et al. (1982) A-W glass with higher metal fluoride content (AW3, Table 2) resulted in a completely changed apatite crystallization behavior. Calver et al. (2004) found that a base glass with the highest $\mathrm{CaF}_{2}$ content favored volume FAp nucleation and crystallization. Calver et al. (2004) also found that A-W systems showed reduced $T_{\mathrm{g}}$ and FAp crystallization exotherms with increasing calcium fluoride content. Therefore, low calcium fluoride content in the original A-W system is actually suppressing crystallization of FAp. Filho et al. (1996) suggest that fully crystallized GCs, which are otherwise bioactive, will not exhibit any further bioactivity through the release of ions, such as $\mathrm{Ca}^{2+}$ and $\mathrm{HPO}_{4}^{2-}$, once such ions take up higher energy coordination states in the apatite lattice. Therefore, from a bioactivity point of view, it may not always be 


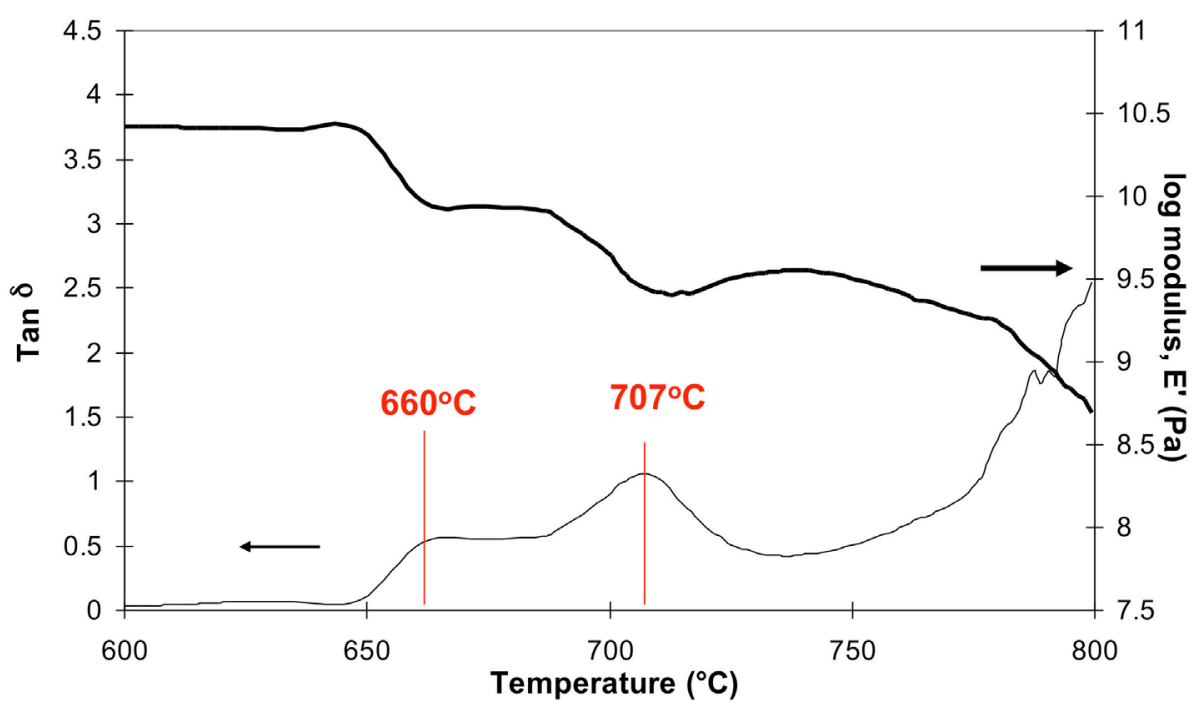

FIGURE 4 | Dynamic mechanical testing analysis (DMTA) of an A-M glass-ceramic showing two glass transitions, one at $660^{\circ} \mathrm{C}$ and second at $707^{\circ} \mathrm{C}$ and two decreases in modulus after Rafferty et al. (2000) collected at a $5^{\circ} \mathrm{C} / \mathrm{min}$ heating rate in a single frequency mode at $1 \mathrm{~Hz}$.

TABLE 2 | A-W base glass compositions in mol\% (Calver et al., 2004).

\begin{tabular}{lccccc}
\hline & $\mathbf{S i O}_{2}$ & $\mathbf{P}_{\mathbf{2}} \mathbf{O}_{5}$ & $\mathbf{M g O}$ & $\mathbf{C a O}$ & $\mathbf{C a F}_{2}$ \\
\hline AW1 & 35.46 & 7.15 & 7.11 & 50.28 & 0 \\
AW2 & 35.46 & 7.15 & 7.11 & 49.88 & 0.4 \\
AW3 & 35.46 & 7.15 & 7.11 & 45.51 & 4.77 \\
\hline
\end{tabular}

desirable to consume therapeutic ions for the formation of apatite within the glass matrix, as opposed to the release of such ions and subsequent formation of apatite on the surfaces of the material, that potentially lead to the formation of a strong and chemically stable implant-bone interface. Furthermore, the molar Ca to $\mathrm{P}$ ratio in a stoichiometric apatite crystal is 10 to 6 (1.67); therefore, GC systems containing a stoichiometric Ca to $\mathrm{P}$ ratio, or in other words, glass formulations with smaller compositional differences between the glass and the crystal phase preferentially crystallize in bulk, which is unfortunately not the case in the A-W system. On the other hand, the A-W system is inherently aluminum free; thus, risks associated with aluminum neurotoxicity, summarized by Kumar and Gill (2009) and reported by Reusche et al. (2001), are completely absent.

It could be argued as to why the original A-W system developed by Kokubo et al. (1982) contains magnesium and a non-stoichiometric Ca:P:F ratio that could otherwise aid bulk nucleation and crystallization of apatite phases. There is a considerable and long-standing proof, for example, as found by X-ray diffraction analyses of precipitated apatites by LeGeros et al. (1980), which demonstrates that the presence of $\mathrm{Mg}^{2+}$ ions in an aqueous solution cause a strain on the apatite structure causing it to collapse and, therefore, suppress its growth. In view of the biological apatite found in bone as opposed to tooth, $\mathrm{Mg}^{2+}$ ions alongside osteocalcine and proteoglycan proteins play a significant role in the development of a nanoscale apatite (Blumenthal et al., 1975), providing the bone tissue with a fine microstructure and the excellent properties that come with it. Therefore, on that basis, it could be argued that the A-W system is highly biomimetic in view of the elemental composition of the human bone.

In vivo animal studies on the implanted $\mathrm{A}-\mathrm{W}$ glass-ceramic provide evidence for excellent osseointegration around the A-W implant and a chemical calcium phosphate-based interface (Kitsugi et al., 1989, 1990) between the implant and bone, with high bending and compressive strengths of 157 and $1060 \mathrm{MPa}$, respectively (Nakamura et al., 1985). Kokubo et al. (1990) found that A-W GC immersed in tris(hydroxymethyl)aminomethane (TRIS) buffer did not show bioactivity through the formation of apatite and these findings were contradictory to animal studies conducted previously, where the A-W GC was found to form a strong chemical interface with the living bone. Therefore, Kokubo et al. (1990) developed a simulated body fluid (SBF), an alternative immersion medium for in vitro assessment of bioactivity of the A-W GC. Kokubo et al. (1990) argued that TRIS buffer does not mimic the actual body environment because it is completely deficient in ions, such as $\mathrm{Ca}^{2+}$ and $\mathrm{HPO}_{4}^{2-}$ naturally found in the bodily fluids and, therefore, argued that the lack of apatite formation in TRIS buffer, as opposed to high bioactivity of the A-W GC in SBF, also supports the view that the apatite phase on the surfaces of the A-W GC forms by a chemical reaction between the A-W GC and the ions present in the body fluid. In view of this, it can be further postulated that apatite crystals within the A-W GC act as nuclei on which ions, such as $\mathrm{Ca}^{2+}$ and $\mathrm{PO}_{4}^{3-}$ in the solution nucleate and feed apatite formation until the eventual fusion between the apatite crystals in the $\mathrm{A}-\mathrm{W}$ and the apatite in the living bone, whereby a chemical interface is formed.

Kokubo et al. (1992) reported that if aluminum is included in the $\mathrm{A}-\mathrm{W}$ parent glass composition and then subsequently crystallized, the A-W GC does not show any bioactivity in SBF 
as opposed to the same $\mathrm{A}-\mathrm{W}$ material without aluminum. The addition of aluminum results in a more chemically stable residual glass phase, which reduces the release of $\mathrm{Ca}^{2+}$ and $\mathrm{PO}_{4}^{3-}$ ions, thereby affecting apatite formation (Strnad, 1992). Later, Blades et al. (1998) conducted in vivo animal study on aluminumcontaining glass ionomer cements (GICs) as potential bone cements, where as low as $1 \mathrm{ppm}$ of aluminum released was found to inhibit mineralization of the newly formed osteoid in rabbit bone. It is important to distinguish that the role of aluminum in Blades et al. (1998) study may be attributed to aluminum toxicity to bone-forming cells (Rodriguez et al., 1990) and direct inhibition of crystal growth as opposed to reduced bioactivity involving structural parameters of the residual glass phase, as proposed in Strnad (1992) study.

Good oseointegration through the formation of apatite on the implant surfaces (Neo et al., 1993) combined with good mechanical properties (Kokubo et al., 1985, 1986) perhaps explains why the A-W glass-ceramic has found promising applications in bone and vertebra replacement (Kokubo, 2008) and it is reported that over 50,000 successful bone implants have been made using the A-W glass-ceramic system (Zanotto, 2010). However, from a manufacturing point of view, a bulk crystallizing A-W material, such as proposed by Calver et al. (2004), could provide a more cost-effective material. In vitro and in vivo bioactivity of the modified A-W system developed by Calver et al. (2004) still needs to be established. The original A-W GC is currently manufactured by Nippon Electric Glass Co., Ltd. (Japan) (Montazerian and Zanotto, 2016).

\section{Fluorapatite-Mica Glass-Ceramics}

Grossman (1972) of Corning Glass Works, developed the first machinable mica glass-ceramic system, later marketed by Dentsply International under the name Dicor ${ }^{\circledR}$. Dicor ${ }^{\circledR}$ was seen as a very significant development since the new GC material could be easily machined to shape without a critical failure. Machinability of the mica glass-ceramics is attributed to the eminent cleavage of the mica-type crystals as a result of anisotropic crystal growth. This facilitates crack propagation in the direction of cutting without causing a critical failure of the material.

Although mica glass-ceramics initially did not contain any apatite phases, Vogel et al. (1986) developed two GC systems (Table 3) with FAp and tri/tetrasilicic $\mathrm{Mg}_{3}\left(\mathrm{AlSi}_{3} \mathrm{O}_{10} \mathrm{~F}_{2}\right) \mathrm{Na} / \mathrm{K} /$ $\mathrm{Mg}_{3}\left(\mathrm{Si}_{4} \mathrm{O}_{10} \mathrm{~F}_{2}\right) \mathrm{Na} / \mathrm{K}$ mica phases and an additional silica-free GC with apatite and aluminum phosphate phases.

Commercially available Bioverit $\mathrm{I}^{\circledR}$ and Bioverit $\mathrm{II}^{\circledR}$ systems crystallize to FAp and mica phases in bulk. Bioverit $\mathrm{II}^{\circledR}$ GC crystallizes to a smaller fraction of FAp, which can be explained by the very low $\mathrm{P}_{2} \mathrm{O}_{5}$ content in the composition (Table 3). Both systems have undergone prior APS into two droplet phases and a glassy matrix phase (Höland and Beall, 2012). One droplet phase is rich in apatite elements whereas the second droplet phase is closer to the mica composition. This may explain why both phases, apatite and mica, crystallize in bulk. Bioverit III is a silica-free phosphate glass that crystallizes to FAp and an aluminum phosphate $\left(\mathrm{AlPO}_{4}\right)($ Höland and Beall, 2012); Bioverit III material exhibits lower mechanical properties (Höland and Beall, 2012); therefore, it has not been so extensively studied.
TABLE 3 | Examples of Bioverit ${ }^{\circledR}$ base glass composition in mol\% (Höland and Vogel, 2013).

\begin{tabular}{lcc}
\hline & Bioverit I & Bioverit II \\
\hline $\mathrm{SiO}_{2}$ & 29.44 & 44.12 \\
$\mathrm{Al}_{2} \mathrm{O}_{3}$ & 9.04 & 17.47 \\
$\mathrm{P}_{2} \mathrm{O}_{5}$ & 4.66 & 0.08 \\
$\mathrm{CaO}$ & 14.89 & 0.21 \\
$\mathrm{MgO}$ & 21.29 & 17.44 \\
$\mathrm{Na}$ & 2.15 & 4.23 \\
$\mathrm{~K}_{2} \mathrm{O}$ & 3.57 & 3.10 \\
$\mathrm{TiO}_{2}$ & - & - \\
$\mathrm{F}$ & 14.96 & 13.17 \\
$\mathrm{Cl}$ & - & 0.17
\end{tabular}

Bioverit II contains a higher fraction of mica crystals. Therefore, Bioverit II GC exhibits better machinability but at the expense of lower mechanical properties than Bioverit I (Table 1). Based on ${ }^{19} \mathrm{~F}$ MAS-NMR experiments of mica ceramics, it was demonstrated that the fluoride ion in mica systems exists mainly in $\operatorname{Mg}(\mathrm{n})-\mathrm{F}$ type environments, with a chemical shift at about -174 ppm for Mg(3)-F (Fechtelkord et al., 2003). As of 2016, A-FM GCs, Bioverit I and II are currently manufactured by VITRON Spezialwerkstoffe GmbH (Germany).

\section{Fluorapatite-Mullite Glass-Ceramics}

Mullite is a rare naturally occurring aluminosilicate mineral. Mullite-reinforced matrices exhibit enhanced mechanical properties. FAp phases can act as nucleation and crystal growth sites for new apatite phases between the implant and living bone. Both crystal phases in the fluorapatite-mullite system show elongated needle-like microstructure and exceptional mechanical properties, particularly flexural strength and fracture toughness of up to $330 \mathrm{MPa}$ and $3.3 \mathrm{MPa} \sqrt{ } \mathrm{m}^{2}$, respectively (Table 1 ). The A-M GC exhibits spherulitic crystallization, which enhances fracture toughness properties of the material (Stanton et al., 2010). The system nucleates in bulk; therefore, it is readily castable by the "lost wax" route.

The first melt-derived castable FAp $\left(\mathrm{Ca}_{5}\left(\mathrm{PO}_{4}\right)_{3} \mathrm{~F}\right)$-mullite $\left(\mathrm{Al}_{6} \mathrm{Si}_{2} \mathrm{O}_{13}\right)$ glass-ceramics were developed by Hill et al. (1991) and were based on the $\mathrm{SiO}_{2}-\mathrm{Al}_{2} \mathrm{O}_{3}-\mathrm{P}_{2} \mathrm{O}_{5}-\mathrm{CaO}-\mathrm{CaF}_{2}$ system. Additionally, Samuneva et al. (1998) were also able to produce an A-M glass-ceramic by a sol-gel route, rather than a melt-quench route.

Hill et al. (1991) noted that base glasses with relatively low $\mathrm{CaF}_{2}$ content (A-C, Table 4) surface crystallized to apatite and mullite phases upon heat treatment, whereas base glasses with metal fluoride content (D and E, Table 4) bulk crystallized to anorthite with only a small fraction of FAp. The work by Hill et al. (1991) and also subsequent work by Hill and Wood (1995); Clifford and Hill (1996); Hill et al. (2000); Rafferty et al. (2000a); Clifford et al. (2001a,b), and later by Stanton and Hill (2005) suggests that metal fluoride as well as phosphorus content in fluoro-phospho-aluminate systems will likely influence prior LLPS and will therefore determine whether the glass crystallizes via the homogenous bulk route (aided by the LLPS composition) or the heterogeneous surface route. 
Stanton and Hill (2005) postulated that once crystallization of FAp crystal has begun, the surrounding glass becomes depleted in $\mathrm{F}, \mathrm{Ca}$, and $\mathrm{P}$ and moves closer to the mullite composition, whereupon, it crystallizes to mullite by the homogenous mechanism. Stamboulis et al. (2004) explained crystallization of FAp and mullite phases in the A-M system in even greater detail by analyzing heat-treated $\mathrm{A}-\mathrm{M}$ samples with magic angle spinningnuclear magnetic resonance (MAS-NMR) spectroscopy. Spectra from ${ }^{27} \mathrm{Al}$ MAS-NMR in Figure 5 (left) show how aluminum resonance is relatively unchanged until the GC reaches second crystallization temperature $\left(T_{\mathrm{p} 2}\right)$ whereupon it crystallizes to mullite. It can be observed from Figure 5 (left) that a broad peak seen at around $50 \mathrm{ppm}$, assigned to $\mathrm{Al}(\mathrm{IV})$, remains unchanged even after FAp crystallization $\left(T_{\mathrm{p} 1}\right)$. During second phase crystallization, an additional peak, at around $12 \mathrm{ppm}$, which is assigned to an $\mathrm{Al}(\mathrm{VI})$ in mullite is observed. Stamboulis et al. (2004) further explain that, during first and second crystallization processes, charge balancing cations for maintaining aluminum in a fourfold coordination state, $\mathrm{Al}(\mathrm{IV})$ are consumed during FAp formation; therefore, at higher temperatures, the lack of charge balancing cations to keep aluminum in a IV coordination state forces aluminum to take up higher coordination states, in this case, $\mathrm{Al}(\mathrm{VI})$. ${ }^{19} \mathrm{~F}$ MAS-NMR spectra as shown in Figure 5 (right) show how the fluorine environment changes with increasing heat-treatment temperature. The lowermost ${ }^{19} \mathrm{~F}$ spectrum of the untreated LG120 glass in Figure 5 (right) demonstrates two broad peaks at $\mathbf{- 9 0}$ and $-150 \mathrm{ppm}$ that can be attributed to the amorphous fluorine environments in the untreated glass, $\mathrm{F}-\mathrm{M}(\mathrm{n})$ and $\mathrm{Al}-\mathrm{F}-\mathrm{M}(\mathrm{n})$

TABLE 4 | A-M base glass compositions in mol\% (Hill et al., 1991).

\begin{tabular}{lccccc}
\hline & $\mathbf{S i O}_{2}$ & $\mathbf{A l}_{2} \mathbf{O}_{\mathbf{3}}$ & $\mathbf{P}_{\mathbf{2}} \mathbf{O}_{\mathbf{5}}$ & $\mathbf{C a O}$ & $\mathbf{C a F}_{\mathbf{2}}$ \\
\hline $\mathrm{A}$ & 37.50 & 25.00 & 12.50 & 25.00 & 0.00 \\
$\mathrm{~B}$ & 35.29 & 23.53 & 11.76 & 23.53 & 5.88 \\
$\mathrm{C}$ & 33.33 & 22.22 & 11.11 & 22.22 & 11.11 \\
$\mathrm{D}$ & 31.58 & 21.05 & 10.53 & 21.05 & 15.79 \\
$\mathrm{E}$ & 30.00 & 20.00 & 10.00 & 20.00 & 20.00
\end{tabular}

(Zeng and Stebbins, 2000). However, at $T_{\mathrm{p} 1}$, a sharp peak at around -103 ppm develops at the expense of $\mathrm{F}-\mathrm{Ca}(\mathrm{n})$ peak, which is assigned to fluorine in a F-Ca(3) environment in FAp. At higher temperatures, such as $T_{\mathrm{p} 2}$, fluorine from $\mathrm{Al}-\mathrm{F}-\mathrm{M}(\mathrm{n})$ peak is also fully consumed and Stamboulis et al. (2004) further proposed that $\mathrm{F}-\mathrm{M}(\mathrm{n})$ such as $\mathrm{F}-\mathrm{Ca}(\mathrm{n})$ species preferentially charge balance the non-bridging oxygens in the phosphorus locality. It can be additionally postulated that such preference to balance the non-bridging oxygens in the phosphorus locality reduces kinetic energy barrier to FAp nucleation and crystal growth, since the local environment of $\mathrm{Ca}, \mathrm{P}$, and $\mathrm{F}$ in the glass is similar to that present in FAp.

Relatively recently, Stamboulis et al. (2006), Hill et al. (2007), and O'Donnell et al. (2010) conducted real-time SANS and neutron diffraction (ND) experiments on the A-M systems developed in the early 1990s. They postulated that amorphous glasses that form the A-M system may have undergone phase separation by spinodal decomposition during the casting process on a scale of 25-27 nm (Hill et al., 2007). Similarly, the same cast A-M system isothermally heat treated at $740^{\circ} \mathrm{C}$ and $750^{\circ} \mathrm{C}$ initially showed neutron scattering at higher $q$, which then moved to lower $q$ with increasing temperatures where the scale of the LLPS corresponded to about $35 \mathrm{~nm}$. This provides evidence that undercooled liquids can undergo LLPS by nucleation and growth, whereupon the chemical system can overcome the thermodynamic and kinetic energy barriers to nucleation and subsequent amorphous phase growth. It is suggested by Hill et al. (2007) that the A-M cast glass is initially phase-separated by spinodal decomposition, whereby rapid cooling creates a barrier to nucleation and growth. However, it may be argued that scattering at lower $q$ in the as-cast glasses may be attributed to a finer LLPS by nucleation and growth. SANS experiments by Hill and coworkers provide evidence that finer scale phase separation in the apatite-mullite system increases in size as a function of temperature, which can be either attributed to the fact that the cast A-M system is initially spinodally decomposed and then undergoes LLPS by
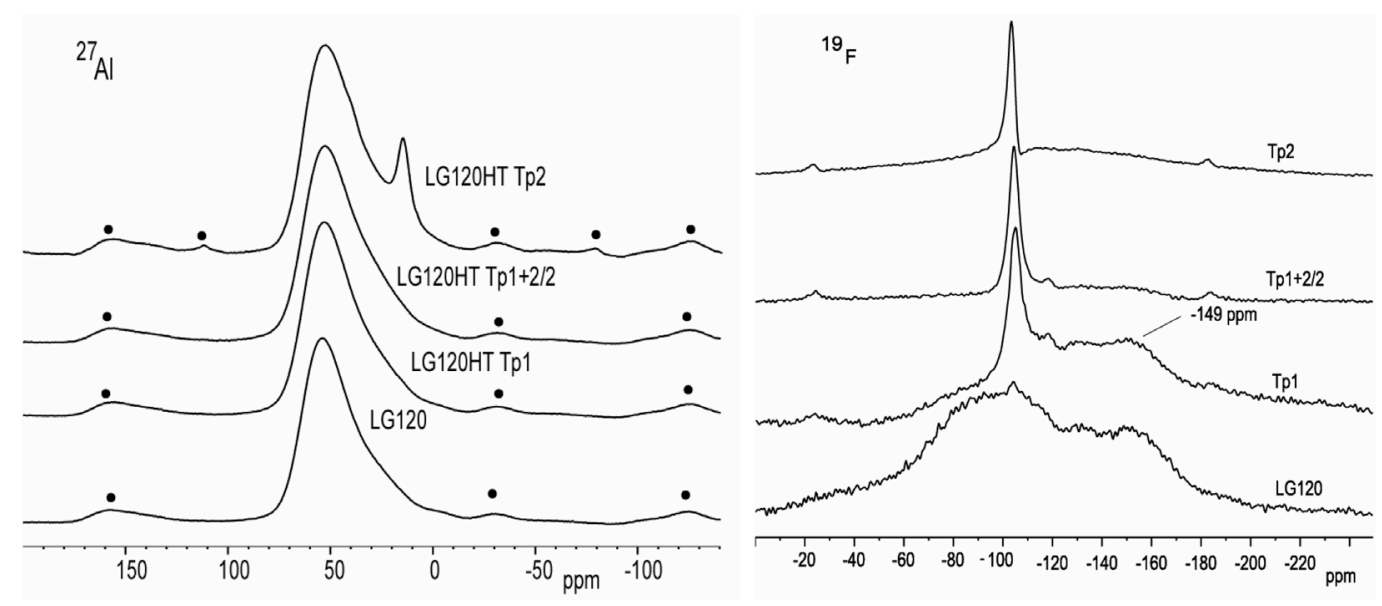

FIGURE $5 \mid{ }^{27} \mathrm{Al}$ (left) and ${ }^{19} \mathrm{~F}$ (right) MAS-NMR spectra of LG120 heat treated at different temperatures (Stamboulis et al., 2004). 
nucleation and growth or more likely LLPS growth by an OR mechanism.

Further studies of an A-M glass-ceramic analyzed by heat treating an amorphous precursor glass up to $1,200^{\circ} \mathrm{C}$ with in situ TOF-ND (O'Donnell et al., 2010) explain the crystallization behavior of the A-M system in more detail. O'Donnell et al. (2010) reported that FAp and mullite crystallized on heating until $1,130^{\circ} \mathrm{C}$ followed by the partial dissolution of both phases at higher temperatures. It was also found that on the subsequent cooling of the A-M system, recrystallization occurred and additional new phases were produced, namely berlinite $\left(\mathrm{AlPO}_{4}\right)$ and cristobalite $\left(\mathrm{SiO}_{2}\right)$, which formed at around $1,025^{\circ} \mathrm{C}$ in addition to the FAp and mullite. This indicates that the subsequent cooling of the GC can produce additional crystal phases, which may be undesirable but can be avoided by introducing higher cooling rates to create an energy barrier to nucleation and growth of the undesirable crystal phases.

Stanton and Hill (2005) found that apatite phases in the A-M system grow as dendrites and spherulites. Generally, the microstructure of a GC is strongly influenced by the conditions of the heat-treatment of the parent glass, this namely includes duration, temperature, and cooling rate and whether or not the base glass compositions is doped with additional nucleants, for example, such as reported with niobium-doped FAp GCs by Denry et al. (2012). Mechanical properties, particularly fracture toughness of the A-M GC developed by Hill and coworkers, surpass mechanical properties of the alternative glass-ceramic systems discussed in this review.

In vivo animal studies conducted by Freeman et al. (2003) show that a fully crystallized A-M glass-ceramic osseointegrates with bone as shown in Figure 6B; however, its amorphous precursor base glass implant does not osseointegrate, which is evident from the fibrous tissue around the glass implant as shown in Figure 6A and the lack of implant/bone interfaces. Goodridge et al. (2007) report on both, in vitro and in vivo properties of the porous A-M glass ceramic system produced through selective laser sintering (SLS) method, using cast A-M and commercial A-W glassceramics as positive controls. In the 4 weeks study, Goodridge et al. (2007) reports that no sign of inflammation or adverse tissue reaction was observed around all the implants. Analyses of the implant-bone interfaces by scanning electron microscopy (SEM) showed evidence for bone ingrowth into the both porous materials, the A-M system produced through SLS method and the A-W sintered glass-ceramic. Although Goodridge et al. (2007) report that the laser sintered apatite-mullite system developed by Hill et al. (1991) does not form apatite in SBF, previous studies indicate that SBF studies are not adequate in the assessment of bioactivity of aluminum-containing GCs (Strnad, 1992).

Stanton et al. (2009) assessed the interfacial chemistry between the A-M system and a titanium alloy, for potential applications of the A-M system for orthopedic implant coatings. Stanton et al. (2009) enameled the A-M glass-ceramic to titanium by heat treatment and thereafter analyzed the interfacial reaction zone between the A-M glass-ceramic and the titanium alloy by highangle annular dark field TEM (HAADF-TEM). Stanton et al. (2009) found that titanium diffused into the intermediate layer of the glass-ceramic and postulated that complex titanium silicides and titanium phosphides were formed based on the elemental analysis of the interfacial zones by energy dispersive $\mathrm{X}$-rays (EDX), which produced characteristic photons for Ti, Si, and $\mathrm{P}$ elements, but not $\mathrm{O}$ elements. This study provides evidence that the A-M system can chemically adhere to titanium. This can be useful in overcoming the problem of coating detachment observed with micromechanical surface retention of plasma sprayed HAp coatings (Filiaggi et al., 1991). The A-M glass-ceramic coating may enhance osseointegration at the bone-implant interface and provide long-term stability of the A-M coated implants.

Wood and Hill (1991) produced cements from the A-M glass-ceramic ionomer-type systems with varying degrees of crystallinity for potential application as bone cements. Wood and Hill (1991) found that the degree of crystallinity of the A-M glass-ceramic can influence the properties of the cements, such as working and setting times of the cement pastes and the mechanical properties of the set cements.

\section{Strontium-Substituted FAp Glass-Ceramics}

Hill et al. (2004) developed strontium-substituted FAp glassceramics for potential orthopedic applications, in the system $\mathrm{SiO}_{2}-\mathrm{Al}_{2} \mathrm{O}_{3}-\mathrm{P}_{2} \mathrm{O}_{5}-\mathrm{CaO} / \mathrm{SrO}-\mathrm{CaF}_{2} / \mathrm{SrF}_{2}$ (Table 5). Since strontium has a higher atomic number than calcium, strontiumsubstituted materials exhibit higher radiopacity, which enables the clinician to distinguish between the implant and bone on a radiograph.

Hill et al. (2004) observed that substituting strontium for calcium has little effect on the parent glass structure. However, the crystallization behavior of the glasses as a function of strontium content was markedly altered. Base glasses without any strontium exhibited complete bulk crystallization with the first crystallization temperature being independent of the particle size, whereas

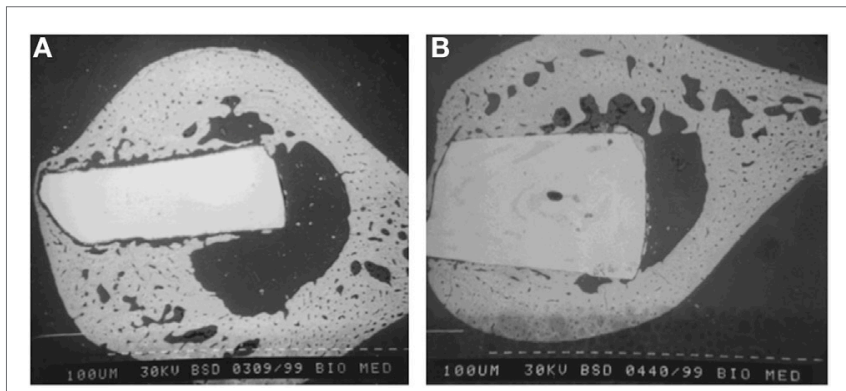

FIGURE 6 | Backscattered scanning electron micrographs of implanted LG120 base glass (A) and implanted LG120 glass-ceramic following subsequent crystallization to fluorapatite and mullite phases (B) (Freeman et al., 2003).

TABLE 5 | Strontium-substituted fluorapatite base glass compositions in mol\% (Hill et al., 2004).

\begin{tabular}{lccccccc}
\hline Glass code & $\mathbf{S i O}_{\mathbf{2}}$ & $\mathbf{A l}_{\mathbf{2}} \mathbf{O}_{\mathbf{3}}$ & $\mathbf{P}_{\mathbf{2}} \mathbf{O}_{\mathbf{5}}$ & $\mathbf{C a O}$ & $\mathbf{C a F}_{\mathbf{2}}$ & $\mathbf{S r O}$ & $\mathbf{S r F}_{\mathbf{2}}$ \\
\hline LG26 & 32.14 & 21.43 & 10.71 & 21.43 & 14.29 & 0.00 & 0.00 \\
LG119 & 32.14 & 21.43 & 10.71 & 10.71 & 14.29 & 10.71 & 0.00 \\
LG125 & 32.14 & 21.43 & 10.71 & 0.00 & 14.29 & 21.43 & 0.00 \\
LG26Sr & 32.14 & 21.43 & 10.71 & 0.00 & 0.00 & 21.43 & 14.29
\end{tabular}


glasses with strontium and no calcium exhibited predominantly surface nucleation. Glasses with equimolar proportions of calcium and strontium crystallized through bulk and surface. Hill et al. (2004) demonstrate that increasing strontium substitution hinders bulk crystallization of apatite, which is reflected in an increase in crystallization temperature, and promotion of surface nucleation of apatite at the expense of bulk nucleation, as evidenced by particle size dependence on the crystallization temperature of the FAp phases. Hill et al. (2004) also observed that equimolar strontium-calcium composition resulted in a glass with a reduced second exotherm associated with mullite crystallization. This can be attributed to an increased mobility of the glass network and a lower glass transition temperature, which produces a more dominant heterogenous crystallization effect. Such a reduction in crystallization temperature would suggest a new crystalline phase, and not simply a reduction in crystallization temperature Hill et al. (2004).

In another study, Hill et al. (2006) elucidated Ca and Sr sites in mixed FAp through ${ }^{19} \mathrm{~F}$ MAS-NMR. Results showed the $\mathrm{F}$ to be present as $\mathrm{F}-\mathrm{Ca}(3)$ in the all calcium glass and as $\mathrm{F}-\mathrm{Sr}(3)$ in the all strontium glass. In the mixed glasses, fluorine was present as mixed sites: F-Ca(3), F-Ca(2)Sr, F-CaSr(2), and F-Sr(3). Ca had a higher tendency to occupy the F-M(3) sites than Sr, which may reflect the higher charge to size ratio of $\mathrm{Ca}^{2+}$ relative to $\mathrm{Sr}^{2+}$ and its greater affinity for $\mathrm{F}^{-}$ions.

An in vivo animal study by Sabareeswaran et al. (2013) on a glass-ceramic that surface crystallized to a strontium FAp phase and a Sr-celsian phase (feldspar) as identified by XRD was found to be highly ossteoconductive and biocompatible. X-ray microtomography (XMT) analyses of the synthetic-organic interfaces showed highly mineralized newly formed bone adjacent to the synthetic implant surface.

It is known that, at low concentrations, strontium can promote mineralization of bone (Verberckmoes et al., 2003). It is also known that strontium-containing bio-glasses show increased osteoblast proliferation and alkaline phosphatase activity (Gentleman et al., 2010). Therefore, it would be desirable to establish ion release (particularly $\mathrm{Sr}^{2+}$ ) profile for the strontium FAp GC systems developed by Hill et al. (2004).

\section{FAp and Chlorapatite Glass-Ceramics}

Recently, Chen et al. (2014a,b) developed novel alkali-free FAp and chlorapatite (ClAp) glass-ceramics from bioactive glasses. Chen et al. (2014a) produced a series of bioactive glasses of varying metal fluoride content and found that bioactive glasses with high fluoride content crystallized to FAp and crystalline $\mathrm{CaF}_{2}$ and $\mathrm{SrF}_{2}$ on quenching. This demonstrates that metal fluoride content can determine crystallization window $\left(T_{\mathrm{x}}\right)$ between the glass transition $\left(T_{\mathrm{g}}\right)$ and the crystallization onset $\left(T_{\text {onset }}\right)$. It is desirable to obtain initially amorphous base glass so that the crystallization of, say a FAp phase, can be controlled. Chen et al. (2014a) also found that the amorphous base glass powder without any fluoride content crystallized to a wollastonite phase through a surface mechanism. Additionally, all fluoride-containing glasses bulk crystallized to FAp via a homogenous nucleation mechanism.

Chen et al. (2014c) were able to develop novel bioactive chloroapatite, ClAp glass-ceramics in the system of
$\mathrm{SiO}_{2}-\mathrm{P}_{2} \mathrm{O}_{5}-\mathrm{CaO}-\mathrm{CaCl}_{2}$. It is known that ClAp completely converts to HAp in the presence of water (Elliott and Young, 1967), hence making ClAp glass-ceramics attractive for both, medical, and dental applications. Chen et al. (2014c) emphasize that ClAp is less stable than FAp. This is attributed to the chloride ion being larger than hydroxyl or fluoride ion. The fluoride ion is small enough to fit in the center of the $\mathrm{Ca}$ (II) triangle in the FAp lattice, whereas larger ions such as hydroxyl and chloride do not fit in the center of the $\mathrm{Ca}$ (II) triangle but are rather displaced above the plane of the $\mathrm{Ca}(\mathrm{II})$ triangle. The chloride ion is larger than hydroxyl ion, and therefore, it is displaced further away from the $\mathrm{Ca}(\mathrm{II})$ triangle. This intrinsic apatite lattice instability brought about by the chloride ion allows the rapid exchange for a smaller ion, such as a hydroxyl ion. On increasing the fluoride or chloride content in the bioactive glass systems, Chen et al. $(2014 b, c)$ found that there was an increasing tendency of the glasses to crystallize. The halogen-free glass surface crystallized to a pseudowollastonite $\left(\alpha-\mathrm{CaSiO}_{3}\right)$ and an apatite, presumably an oxyapatite. Pseudowollastonite induces apatite formation in SBF (Siriphannon et al., 2000) and is highly resorbable in vivo (De Aza et al., 2000). ClAp phases in the Chen et al. (2014b) crystallized via the homogenous route, which from a material processing point of view is highly desirable. FAp is largely insoluble in vivo so ClAp GCs offer the potential for producing highly resorbable GC implants. Nonetheless, there is a need for further characterization of these ClAp GCs, including characterization of the in vivo activity and the relationships between the composition, heat-treatment, microstructure, and mechanical properties.

\section{Dentistry}

\section{FAp-Leucite Glass-Ceramics}

Höland et al. (1994) developed FAp-leucite ( $\left.\mathrm{KAlSi}_{2} \mathrm{O}_{6}\right)(\mathrm{A}-\mathrm{L})$ glass-ceramics in the $\mathrm{SiO}_{2}-\mathrm{Al}_{2} \mathrm{O}_{3}-\mathrm{Na}_{2} \mathrm{O}-\mathrm{K}_{2} \mathrm{O}-\mathrm{P}_{2} \mathrm{O}_{5}-\mathrm{F}$ system, for potential application in restorative dentistry. Research led by Höland led to the development of the commercial A-L glass-ceramic IPS d.SIGN (Ivoclar Vivadent, Liechtenstein). Needle-like apatite phase in the A-L system crystallized through a homogenous crystallization mechanism, which is a likely indication of prior LLPS. Additionally, upon DSC analyses of the A-L system, Höland et al. (2000) observed a unique phenomenon; the A-L system exhibits two endothermic reactions, first at $565^{\circ} \mathrm{C}$ and second endothermic reaction at $634^{\circ} \mathrm{C}$. Previously, the two endothermic reactions were assigned to a phase transformation into two amorphous phases; one glassy, silica-rich phase and a droplet-like phase rich in $\mathrm{Ca}$ and $\mathrm{P}$ elements. Höland et al. (2000) suggests that the second endothermic reaction at $634^{\circ} \mathrm{C}$ is a transformation to a crystal phase, namely a sodium-calcium orthophosphate $\left(\mathrm{NaCaPO}_{4}\right)$, which was confirmed by XRD analysis. Furthermore, Höland et al. (2000) observed another interesting phenomena; at higher temperatures $\left(640^{\circ} \mathrm{C}\right)$, $\mathrm{NaCaPO}_{4}$ crystals dissolved and recrystallized to a new crystal phase. However, this new crystal phase could not be matched to any known phases when checked against the International Center of Diffraction Data (ICDD) database. Additionally, Höland et al. (2000) found that once the new phase is formed, apatite crystallization proceeds at $700^{\circ} \mathrm{C}$. Heat treatment of the $\mathrm{A}-\mathrm{L}$ system at $700^{\circ} \mathrm{C}$ for $8 \mathrm{~h}$ does not result in a material with needle-like 
microstructure; it requires additional heat treatment at $1,050^{\circ} \mathrm{C}$ for $2 \mathrm{~h}$ for the development of needle-like FAp crystals (Höland et al., 2000). This demonstrates that the thermal treatment of the base glass can strongly influence both, the appearance and other properties of the GC material.

Höland et al. (2000) suggest that the morphology of the needle-like apatite is comparable to that of the apatite in natural teeth; therefore, such needle-like FAp morphology imparts the $\mathrm{GC}$ restoration with exceptional esthetics. The A-L glass-ceramic exhibits good chemical durability, solubility of the GC being only at $60-70 \mu \mathrm{g} / \mathrm{cm}^{2}$. Translucency of the A-L system varies between 5.8 and $10.4 \%$, depending on the mode of processing. The $\mathrm{A}-\mathrm{L}$ shows thermal expansion of $14.1-14.8 \times 10^{-6} \mathrm{~K}^{-1}$, which is close to that of titanium; therefore, the $\mathrm{A}-\mathrm{L}$ glass-ceramic is highly suitable for direct sintering on metal abutments. Since 1998, there have been more than 60 million dental restorations performed using commercial IPS d.SIGN ${ }^{\circledR}$ A-L glass-ceramic (Höland and Rheinberger, 2008), making it the most commercially successful apatite glass-ceramic developed to date.

\section{Strontium-Substituted A-L Glass-Ceramics}

Höland et al. (2015) developed radiopaque strontium FAp (Sr-FAp) containing glass-ceramics (Table 6) for dental applications where Sr-FAp phase crystallized through homogenous mechanisms. Höland et al. (2015) were also able to obtain secondary and tertiary crystal phases, in addition to $\mathrm{Sr}$-FAp, including leucite $\left(\mathrm{KAlSi}_{2} \mathrm{O}_{6}\right)$, rubidium leucite $\left(\mathrm{RbSi}_{2} \mathrm{O}_{6}\right)$, cesium pollucite $\left(\mathrm{CsAl}_{2} \mathrm{~S}_{2} \mathrm{O}_{6}\right)$, and sodium strontium orthophpshate $\left(\mathrm{NaSrPO}_{4}\right)$. However, both leucite phases and pollucite phases showed surface crystallization. Höland et al. (2015) found that some of the base glasses that were rapidly quenched into water (to prevent crystallization) did not avoid crystallization completely. Based on XRD analyses of all parent glasses, Höland et al. (2015) found that all glasses, except reference glass No. 5, were nanocrystalline. XRD analyses of the base glasses No. 1 and No. 2 showed the presence of nanoscale $\mathrm{Sr}_{5}\left(\mathrm{PO}_{4}\right)_{3} \mathrm{~F}$, whereas base glasses No. 3 and 4 contained nanocrystalline phases of $\mathrm{NaSrPO}_{4}$. Höland et al. (2015) also report that only two of the "as-quenched" base glasses were optically clear, namely, No. 1 and 5, as opposed to base glasses No. 2, 3, and 4, which were opalescent in the visible light. Höland et al. (2015) showed that Sr-FAp glass-ceramics are radiopaque; therefore, these dental GCs may become more clinically relevant once commercialized.

\section{NANOSCALE APATITE GLASS-CERAMICS AND OPTOELECTRONICS}

Glass-ceramics containing nanoscale phases of crystals are produced by carefully controlling heat treatments of the parent glasses, in which the nucleation rate is enhanced and the crystal growth rate is low. Crystal growth rates can be suppressed by keeping the crystal growth temperature close to $T_{\mathrm{g}}$. The $T_{\mathrm{g}}$ of the residual glass phase increases as crystallization occurs. Crystallization of fluorine containing phases, such as FAp is particularly attractive here since a reduction in fluorine content in the residual glass phase results in a large increase
TABLE 6 | Strontium fluorapatite base glass compositions in $\mathrm{mol} \%$ (Höland et al., 2015).

\begin{tabular}{|c|c|c|c|c|c|}
\hline Glass code & 1 & 2 & 3 & 4 & 5 \\
\hline $\mathrm{SiO}_{2}$ & 58.7 & 59.4 & 60.4 & 61.1 & 66 \\
\hline $\mathrm{Al}_{2} \mathrm{O}_{3}$ & 9 & 9.1 & 9 & 9.1 & 8.5 \\
\hline $\mathrm{Y}_{2} \mathrm{O}_{3}$ & 3.1 & 2.2 & 0.1 & 0.1 & - \\
\hline $\mathrm{La}_{2} \mathrm{O}_{3}$ & - & - & 0.3 & - & - \\
\hline $\mathrm{CaO}$ & - & - & - & - & 1.8 \\
\hline $\mathrm{SrO}$ & 5.5 & 5.5 & 7.9 & 5.9 & - \\
\hline $\mathrm{ZnO}$ & - & - & - & - & 1.3 \\
\hline $\mathrm{Na}_{2} \mathrm{O}$ & 10.1 & 10.2 & 8.4 & 10 & 8.9 \\
\hline $\mathrm{K}_{2} \mathrm{O}$ & 7.5 & 7.6 & 2.6 & 2.7 & 6.4 \\
\hline $\mathrm{P}_{2} \mathrm{O}_{5}$ & 1.8 & 1.8 & 1.8 & 1.7 & 0.2 \\
\hline $\mathrm{F}$ & 2.4 & 2.3 & 2.6 & 2.4 & 3.2 \\
\hline $\mathrm{Cs}_{2} \mathrm{O}$ & - & - & 4.9 & - & - \\
\hline $\mathrm{Rb}_{2} \mathrm{O}$ & - & - & - & 4.8 & - \\
\hline $\mathrm{ZrO}_{2}$ & 0.5 & 0.5 & 0.5 & 0.6 & 2.1 \\
\hline $\mathrm{TiO}_{2}$ & 0.2 & 0.2 & 0.2 & 0.2 & 1.2 \\
\hline $\mathrm{CeO}_{2}$ & 0.4 & 0.4 & 0.4 & 0.4 & 0.3 \\
\hline $\mathrm{B}_{2} \mathrm{O}_{3}$ & 0.3 & 0.3 & 0.4 & 0.2 & 0.1 \\
\hline $\mathrm{Li}_{2} \mathrm{O}$ & 0.5 & 0.5 & 0.5 & 0.8 & - \\
\hline Crystal phase & $\begin{array}{c}\mathrm{Sr}_{5}\left(\mathrm{PO}_{4}\right)_{3} \mathrm{~F} \\
\mathrm{KAISi}_{2} \mathrm{O}_{6}\end{array}$ & $\begin{array}{l}\mathrm{Sr}_{5}\left(\mathrm{PO}_{4}\right)_{3} \mathrm{~F} \\
\mathrm{KAISi}_{2} \mathrm{O}_{6} \\
\mathrm{NaSrPO}_{4}\end{array}$ & $\begin{array}{c}\mathrm{Sr}_{5}\left(\mathrm{PO}_{4}\right)_{3} \mathrm{~F} \\
\mathrm{CsAlSi}_{2} \mathrm{O}_{6} \\
\mathrm{NaSrPO}_{4}\end{array}$ & $\begin{array}{c}\mathrm{Sr}_{5}\left(\mathrm{PO}_{4}\right)_{3} \mathrm{~F} \\
\mathrm{RbAlSi}_{2} \mathrm{O}_{6} \\
\mathrm{NaSrPO}_{4}\end{array}$ & $\mathrm{Ca}_{5}\left(\mathrm{PO}_{4}\right)_{3} \mathrm{~F}$ \\
\hline
\end{tabular}

in $T_{\mathrm{g}}$. Alternatively, nanocrystalline phases in GCs can be obtained by developing parent glasses that phase-separate on a nanoscale, whereby subsequent crystal growth is limited by the boundaries of the LLPS domain, provided the parent glass does not overcome kinetic energy barrier to OR during heat treatment. Regardless of the application of the nano-GCs, the size and microstructure of apatite crystals are very important factors that determine whether a glass-ceramic is opaque or transparent after crystallization. Transparent GCs contain crystals smaller than the wavelength of light. Such nanoscale GCs are used for different applications, ranging from transparent zero thermal expansion coefficient cooking hobs, consumer electronics to laser amplifiers in optoelectronics. Transparency of the GC is highly desirable in these applications because light transmission through a transparent GC is highly efficient due to no or low internal light scattering.

Rare earth elements, such as those in the lanthanide group have special photon absorption and reemission properties. Under near-infrared excitation, rare earth elements can absorb low energy photons and reemit high energy photons (anti-Stokes emission). In contrast, quantum dots or organic dyes, on the other hand, are excited by high-energy photons but reemit lowenergy photons (Stokes emission), which exhibit luminescence in the visible spectrum.

Glasses and glass-ceramics doped with rare earth elements exhibit special optical properties. Such glasses and glass-ceramics are used for applications in solid-state lasers, optical amplifiers, and display screens. Glasses doped with rare earth elements usually exhibit broader spectral bands and smaller absorption and reemission characteristics as compared to glass-ceramics, which are more efficient and show higher absorption and re-emission characteristic in addition to narrower spectral bands (Zhang et al., 2012, 2013a,b). 
Furthermore, fluoride-containing crystals such as FAp are also known to have low phonon energies and low-dielectric loss, which is an attractive property in optoelectronics. Despite the commercial use of single crystal lasers based on apatites and the fact that apatite lattices are also very attractive for accommodating rare earth ions, there is limited number of publications on nanocrystalline apatite glass-ceramics since the first patent publication by Pinckney and Dejneka (1998).

Tulyaganov (2000) developed FAp $\left(\mathrm{Ca}_{5}\left(\mathrm{PO}_{4}\right)_{3} \mathrm{~F}\right)$-anorthite $\left(\mathrm{CaAl}_{2} \mathrm{Si}_{2} \mathrm{O}_{8}\right)$-diopside $\left(\mathrm{CaMgSi}_{2} \mathrm{O}_{6}\right)$ glass-ceramics in the system of $\mathrm{SiO}_{2}-\mathrm{Al}_{2} \mathrm{O}_{3}-\mathrm{P}_{2} \mathrm{O}_{5}-\mathrm{CaO}-\mathrm{CaF}_{2}-\mathrm{MgO}$ (Table 7) for potential applications in optical amplifiers. In the above system, FAp crystallization was through a homogenous mechanism, whereas anorthite and diposide phases crystallized via a surface mechanism.

Hill et al. (2010) found evidence that FAp crystallization in the GC developed by Tulyaganov (2000) was on a nanoscale and self-limiting. Hill et al. (2010) provide evidence that FAp crystallization is self-limiting because the system exhibits LLPS on a nanoscale, i.e., the size of the phase-separated domain restricts subsequent crystal growth such that it cannot grow easily beyond the bounds of the LLPS. Hill et al. (2010) also argued that if the crystallization of the fluorine-containing crystal phase occurs close to the glass transition temperature and the crystallization process results in a significant increase in the glass transition temperature, the surrounding "glassy" phase will limit further crystal growth because of the increased glass transition temperature. Hill et al. (2010) proposed that metal fluoride content at or below the stoichiometry of the FAp crystal is one of the factors needed to obtain nanoscale phases of FAp in the GC studied. These results are explained in terms of an approach, which views glasses as being inorganic polymers where the presence of fluorine disrupts the glass network, and thereby reduces the energy barrier to homogeneous nucleation and crystallization of the FAp phases. Notably, Hill et al. (2010) also found some evidence that Mg can occupy $\mathrm{Ca}$ (II) sites of the FAp lattice, which was previously unknown in GCs. It is widely known that $\mathrm{Mg}^{2+}$ cations limit apatite crystal growth by blocking surface sites on the FAp crystal.

Doped single crystal FAp have been considered for potential applications in lasers (Ohlmann et al., 1968; Deloach et al., 1993, 1994). However, their poor thermomechanical properties

TABLE 7 | Fluorapaite-anorthite-diposide base glass composition in mol\%.

\begin{tabular}{cccccc}
\hline $\mathrm{SiO}_{2}$ & $\mathrm{Al}_{2} \mathrm{O}_{3}$ & $\mathrm{P}_{2} \mathrm{O}_{5}$ & $\mathrm{CaO}$ & $\mathrm{CaF}_{2}$ & $\mathrm{MgO}$ \\
\hline 34.7 & 11.1 & 5.4 & 37.2 & 1.8 & 9.7
\end{tabular}

(Hopkins et al., 1971; Payne et al., 1994) can result in beam distortion due to thermal distortion that produces refractive index variations within the crystal. Furthermore, production of single crystals of FAp is not only expensive but unlike a glass-ceramic route cannot be processed into fibers and complex shapes. Polycrystalline apatites generally result in an opaque material, which is undesirable for optoelectronics unless the crystals are nanoscale and less than the wavelength of light. Consequently, nanocrystalline FAp GCs are of particular interest.

Zhang et al. (2012, 2013a,b) developed Nd and Eu-doped visually transparent FAp glass-ceramics (Table 8) for potential applications in optical amplifiers. Nd and Eu ions are f-block elements and can exhibit high degree of up-conversion in appropriate crystal lattices; therefore, they are highly attractive dopants in rare earth accommodating lattices, such as the apatite. Zhang et al. (2012, 2013a,b) systems crystallize to FAp and mullite; therefore, careful control of the heat treatment is crucial to avoid the crystallization of the mullite phase.

The ZH1 Nd doped glass (Table 8), as compared to its undoped version, showed a markedly reduced FAp crystallization temperature, in contrast, $\mathrm{ZH} 3$, strontium version of the same parent glass (Table 8) did not show a reduction in crystallization temperature but rather a less pronounced area under the exotherm assigned to FAp. Furthermore, although Zhang et al. (2013b) systems contain strong nucleants, such as $\mathrm{P}_{2} \mathrm{O}_{5}$, comparing DSC traces of doped and undoped $\mathrm{ZH} 3$ versions, less pronounced FAp exotherms observed with $\mathrm{Nd}$ doped GC may be attributed to enhanced heterogenous nucleation mechanism, as opposed to reduced overall crystallization; however, such explanation would have to be confirmed by analyzing particle size dependence on the crystallization temperature. Notably, Zhang et al. (2012) system ( $\mathrm{ZH} 1$, Table 8 ) could remain optically clear after 24 -h heat treatment at $790^{\circ} \mathrm{C}$. This indicates that Zhang et al. (2012) system has undergone LLPS on a nanoscale, which therefore restricts FAp growth beyond the LLPS domain. Additionally, the kinetic barrier to OR during heat treatment is, therefore, not overcome in Zhang et al. (2012, 2013a,b) systems, which prevents crystal growth into the light scattering dimensions.

Furthermore, SrFAp (Zhang et al., 2013b), as opposed to CaFAp (Zhang et al., 2012), GC was found to have a markedly reduced visible spectrum transmittance, which authors attributed to a lower volume fraction of SrFAp crystals $(12 \pm 2 \%)$ as opposed to volume fraction of CaFAp $(19 \pm 6 \%)$ in the alternative calciumcontaining GC system. Additionally, Zhang et al. (2012) found that Nd-doped calcium FAp GC showed better absorption and emission properties as compared to a strontium FAp GC (Zhang et al., 2013b) and argued that better absorption and emission

TABLE 8 | Compositions of Nd and Eu doped base glasses in mol\% (Zhang et al. (2012, 2013a,b)).

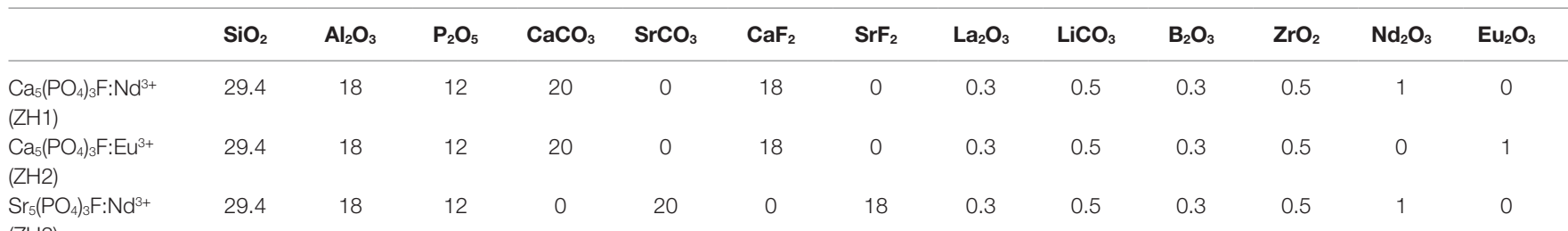

(ZH3) 
properties of a calcium FAp GC may be attributed to a higher fraction of $\mathrm{Nd}$ ions being incorporated into the former crystal lattice. Therefore, Nd-doped calcium FAp GCs likely have an advantage over Nd-doped strontium FAp GCs.

Nonetheless, Zhang et al. (2012, 2013a,b) were able to closely match the refractive index between the glass matrix and the crystal phases for smooth photon transitions across the medium. Additionally, the crystals in the GCs are smaller than the excitation and emission wavelengths and, therefore, such crystals are outside of the light scattering dimensions that in turn produce an energy-efficient material for luminescence applications.

\section{NUCLEAR WASTE IMMOBILIZATION}

Currently, high-level radioactive waste (HLW) from nuclear fission products are fused at high temperatures $\left(\sim 1,250^{\circ} \mathrm{C}\right)$ with a borosilicate glass and subsequently stored in repositories. However, due to long half-life of $\alpha$-emitting radioactive elements, these HLW can potentially only be stored for up to 300 years in these glass matrices. GC, on the other hand, can provide a useful alternative for nuclear waste immobilization because they will provide two barriers of containment: one being the host crystal phase(s) and second the amorphous glass matrix. Additionally, a devitrified material is more resistant to water due to a higher network connectivity of the residual glassy phase.

Weber et al. (1979) and Weber (1993) analyzed Cm-doped silicates with the apatite structure but found them to be poor nuclear waste hosts as they completely transformed into an amorphous state. This resulted in a volume expansion and microfracturing of the material.

It is quite important to point out that phosphate apatite, as opposed to other apatitic phases show better resistance to amorphization (due to nuclear decay) and better chemical stability. Soulet et al. (2001) demonstrated that phosphosilicate FAp ceramics exhibit increasing resistance to amorphization when $\mathrm{SiO}_{4}$ is substituted by $\mathrm{PO}_{4}$. Fang et al. (2014) also found that phosphate apatites exhibit superior chemical stability (under acetic acid challenge) when the atomic proportion of phosphorus replaced by silicon and sulfur did not exceed one-third.

At the Atomic Weapons Establishment (UK), Donald et al. (2007) developed novel calcium phosphate-based halogencontaining calcium apatite ceramics for a universal actinide- and halide-containing waste immobilization. In the preliminary study, Donald et al. (2007) produced four types of experimental halide-containing nuclear waste streams, in addition to a series of mainly sodium aluminum phosphate (NaAlP) glasses for subsequent encapsulation of the waste-hosting calcium phosphate ceramics. However, it is important to underline that apatite ceramics developed by Donald et al. (2007) require additional encapsulation in a durable glass matrix. Therefore, it may be argued that systems developed by Donald et al. (2007) are not traditional GCs; however, research led by Donald et al. (2007) is still ongoing. From a manufacturing point of view, developing a "traditional" apatite GC could possibly provide a more economical alternative. Nonetheless, apatite-containing glass-ceramics are potentially excellent candidates as nuclear waste hosts, which evident from studies on the apatite ceramic materials. Therefore, there is a great but challenging potential for new developments in this field.

\section{CONCLUSION}

The review provides an overview of the apatite glass-ceramics, their crystallization behavior, their remarkable properties, and commercial applications in the fields of medicine and dentistry, optoelectronics, and potential nuclear waste management.

The A-W glass-ceramic discussed in the review shows excellent osseointegration and exhibits clinically suitable mechanical properties, including fracture toughness and flexural strength. However, the failure of this system to bulk nucleate and a lack of bioresorbablity open up new challenging fronts for research and development to overcome these drawbacks. Data on the newly developed chlorapatite GCs suggest that these materials may provide the desired resorbability and osseointegration; however, further work is required in terms of their in vivo activity and structure-property relationship, including the microstructure and mechanical properties.

To date, the most commercially successful apatite glassceramics are those developed for dental veneering. These dental GCs exhibit low solubility, excellent translucency, and clinical esthetics, and are biomimetic in nature.

Current information in the literature suggests that apatite is potentially a good host phase for radioactive waste entrapment. Apatite glass-ceramics would be highly attractive for this application; however, a lack of publications in this area suggests that further studies are required.

The authors would like to conclude that apatite lattice inherently exhibits ease of solid solution whereby various ionic substitutions can take place. As such, its solid-state chemistry is of great interest in both, the fundamental as well as the applied research. Understanding derived from research in apatitecontaining glass-ceramics continues to intrigue and convey new concepts in structural solid-state chemistry and the applied sciences discussed in this review with undoubtedly a great future potential.

\section{AUTHOR CONTRIBUTIONS}

TD produced the manuscript. SS and RH contributed to the critical revision and direction of the manuscript.

\section{FUNDING}

The authors would like to thank Cera Dynamics Limited, part of the James Kent Group and the Institute of Dentistry (Queen Mary University of London) for jointly funding TD. 


\section{REFERENCES}

An, Y. H., and Draughn, R. A. (2000). Mechanical Testing of Bone and the BoneImplant Interface. Boca Raton: CRC Press.

Blades, M., Moore, D., Revell, P., and Hill, R. (1998). In vivo skeletal response and biomechanical assessment of two novel polyalkenoate cements following femoral implantation in the female New Zealand White rabbit. J. Mater. Sci. Mater. Med. 9, 701-706. doi:10.1023/A:1008990516159

Blumenthal, N. C., Betts, F., and Posner, A. S. (1975). Effect of carbonate and biological macromolecules on formation and properties of hydroxyapatite. Calcif. Tissue Res. 18, 81-90. doi:10.1007/BF02546228

Cahn, J. W. (1969). The metastable liquidus and its effect on crystallization of glass. J. Am. Ceram. Soc. 52, 4. doi:10.1111/j.1151-2916.1969.tb11194.x

Calver, A., Hill, R. G., and Stamboulis, A. (2004). Influence of fluorine content on the crystallization behavior of apatite-wollastonite glass-ceramics. J. Sci. Mater. 39, 2601-2603. doi:10.1023/B:JMSC.0000020038.79675.0f

Chen, X., Brauer, D. S., Wilson, R. M., Hill, R. G., and Karpukhina, N. (2014a). Bioactivity of sodium free fluoride containing glasses and glass-ceramics. Materials 7, 5470-5487. doi:10.3390/ma7085470

Chen, X., Brauer, D. S., Wilson, R. M., Hill, R. G., and Karpukhina, N. (2014b). Novel alkali free bioactive fluorapatite glass ceramics. J. Non Cryst. Solids 402, 172-177. doi:10.1016/j.jnoncrysol.2014.05.025

Chen, X., Hill, R., and Karpukhina, N. (2014c). Chlorapatite glass-ceramics. Int. J. Appl. Glass Sci. 5, 207-216. doi:10.1111/ijag.12082

Clifford, A., and Hill, R. (1996). Apatite-mullite glass-ceramics. J. Non Cryst. Solids 196, 346-351. doi:10.1016/0022-3093(95)00611-7

Clifford, A., Hill, R., Towler, M., and Wood, D. (2001a). The crystallisation of glasses from the ternary $\mathrm{CaF}_{2}-\mathrm{CaAl}_{2} \mathrm{Si}_{2} \mathrm{O}_{8}-\mathrm{P}_{2} \mathrm{O}_{5}$ system. J. Sci. Mater. 36, 3955-3961. doi:10.1023/A:1017974306184

Clifford, A., Hill, R., Rafferty, A., Mooney, P., Wood, D., Samuneva, B., et al. (2001b). The influence of calcium to phosphate ratio on the nucleation and crystallization of apatite glass-ceramics. J. Mater. Sci. Mater. Med. 12, 461-469. doi:10.1023/A:1011213406951

De Aza, P. N., Luklinska, Z. B., Martinez, A., Anseau, M. R., Guitian, F., and De Aza, S. (2000). Morphological and structural study of pseudowollastonite implants in bone. J. Microsc. 197(Pt 1), 60-67. doi:10.1046/j.1365-2818.2000. 00647.x

Deloach, L., Payne, S., Chase, L., Smith, L., Kway, W., and Krupke, W. (1993). Evaluation of absorption and emission properties of $\mathrm{Yb}-3+$ doped crystals for laser applications. IEEE J. Quant. Electron. 29, 1179-1191. doi:10.1109/3.214504

Deloach, L., Payne, S., Smith, L., Kway, W., and Krupke, W. (1994). Laser and spectroscopic properties of Sr-5(PO4)(3)F-Yb. J. Opt. Soc. Am. B 11, 269-276. doi:10.1364/JOSAB.11.000269

Denry, I., Holloway, J., and Gupta, P. (2012). Effect of crystallization heat treatment on the microstructure of niobium-doped fluorapatite glass-ceramics. J. Biomed. Mater. Res. B Appl. Biomater. 100B, 1198-1205. doi:10.1002/jbm.b.32684

Donald, I., Metcalfe, B., Fong, S., Gerrard, L., Strachan, D., and Scheele, R. (2007). A glass-encapsulated calcium phosphate wasteform for the immobilization of actinide-, fluoride-, and chloride-containing radioactive wastes from the pyrochemical reprocessing of plutonium metal. J. Nucl. Mater. 361, 78-93. doi:10.1016/j.jnucmat.2006.11.011

Ducheyne, P., Healy, K. E., Grainger, D. W., Hutmacher, D. W., and Kirkpatrick, C. J. (2011). Comprehensive Biomaterials. Oxford: Elsevier.

Elliott, J. C., and Young, R. A. (1967). Conversion of single crystals of chlorapatite into single crystals of hydroxyapatite. Nature 214, 904-906.

Fang, Y., Ritter, C., and White, T. (2014). Crystal chemical characteristics of ellestadite-type apatite: implications for toxic metal immobilization. Dalton Trans. 43, 16031-16043. doi:10.1039/C4DT02088J

Fechtelkord, M., Behrens, H., Holtz, F., Fyfe, C., Groat, L., and Raudsepp, M. (2003). Influence of F content on the composition of Al-rich synthetic phlogopite: Part 1. New information on structure and phase-formation from Si-29, H-1, and F-19 MAS NMR spectroscopies. Am. Mineral. 88, 47-53. doi:10.2138/ am-2003-0106

Filho, O. P., Latorre, G. P., and Hench, L. L. (1996). Effect of crystallization on apatite-layer formation of bioactive glass $45 \mathrm{~S}_{5}$. J. Biomed. Mater. Res. 30, 509-514. doi:10.1002/(SICI)1097-4636(199604)30:4<509::AID-JBM9>3.0.CO;2-T

Filiaggi, M. J., Coombs, N. A., and Pilliar, R. M. (1991). Characterization of the interface in the plasma-sprayed HA coating/Ti-6Al-4V implant system. J. Biomed. Mater. Res. 25, 1211-1229. doi:10.1002/jbm.820251004
Freeman, C. O. I, Brook, M., Johnson, A., Hatton, P. V., Hill, R. G., and Stanton, K. T. (2003). Crystallization modifies osteoconductivity in an apatite-mullite glassceramic. J. Mater. Sci. Mater. Med. 14, 985-990. doi:10.1023/A:1026306901058

Gentleman, E., Fredholm, Y. C., Jell, G., Lotfibakhshaiesh, N., O’Donnell, M. D., Hill, R. G., et al. (2010). The effects of strontium-substituted bioactive glasses on osteoblasts and osteoclasts in vitro. Biomaterials 31, 3949-3956. doi:10.1016/j. biomaterials.2010.01.121

Goodridge, R. D., Wood, D. J., Ohtsuki, C., and Dalgarno, K. W. (2007). Biological evaluation of an apatite-mullite glass-ceramic produced via selective laser sintering. Acta Biomater. 3, 221-231. doi:10.1016/j.actbio.2006.10.005

Grossman, D. G. (1972). Machinable glass-ceramics based on tetrasilicic mica. J. Am. Ceram. Soc. 55, 446-449. doi:10.1111/j.1151-2916.1972.tb11337.x

Hill, R., Calver, A., Skinner, S., Stamboulis, A., Law, R., Nakamura, T., et al. (2006). A MAS-NMR and combined Rietveldt study of mixed calcium/strontium fluorapatite glass-ceramics. Bioceramics 18(Pts 1 and 2), 309-311:305-308. doi:10.4028/www.scientific.net/KEM.309-311.305

Hill, R., Calver, A., Stamboulis, A., and Bubb, N. (2007). Real-time nucleation and crystallization studies of a fluorapatite glass-ceramics using small-angle neutron scattering and neutron diffraction. J. Am. Ceram. Soc. 90, 763-768. doi:10.1111/j.1551-2916.2006.01474.x

Hill, R., Patel, M., and Wood, D. J. (1991). "Preliminary studies on castable apatite-mullite glass-ceramics," in 4th International Symposium on Ceramics in Medicine (London: Butterworth Heineman Ltd.).

Hill, R., Rafferty, A., Mooney, P., and Wood, D. (2000). The influence of glass composition on nucleation crystallisation microstructure and properties of apatite-mullite glass-ceramics. Glass Sci. Technol. 73(1 Suppl. C), 146-153.

Hill, R., and Wood, D. (1995). Apatite-mullite glass-ceramics. J. Mater. Sci. Mater. Med. 6, 311-318.

Hill, R. G., O’Donnell, M. D., Law, R. V., Karpukhina, N., Cochrane, B., and Tulyaganov, D. U. (2010). The early stages of nucleation and crystallisation of an apatite glass-ceramic: evidence for nano-scale crystallisation. J. Non Cryst. Solids 356, 2935-2941. doi:10.1016/j.jnoncrysol.2010.05.102

Hill, R. G., Stamboulis, A., Law, R. V., Clifford, A., Towler, M. R., and Crowley, C. (2004). The influence of strontium substitution in fluorapatite glasses and glass-ceramics. J. Non Cryst. Solids 336, 223-229. doi:10.1016/ j.jnoncrysol.2004.02.005

Höland, W., and Beall, G. H. (2012). Glass-Ceramic Technology. Hoboken, NJ; Westerville, $\mathrm{OH}$ : Wiley; The American Ceramic Society.

Höland, W., Frank, M., Schweiger, M., and Rheinberger, V. (1994). Development of translucent glass-ceramics for dental application. Glastech. Ber. Glass Sci. Technol. 67, 117-122.

Höland, W., and Rheinberger, V. (2008). "Dental glass-ceramics," in Bioceramics and Their Clinical Applications, ed. T. Kokubo (Cambridge, England: Woodhead Publishing Limited), 561.

Höland, W., Rheinberger, V., Wegner, S., and Frank, M. (2000). Needle-like apatite-leucite glass-ceramic as a base material for the veneering of metal restorations in dentistry. J. Mater. Sci. Mater. Med. 11, 11-17. doi:10.1023/ A: 1008977416834

Höland, W., Schweiger, M., Dittmer, M., and Ritzberger, C. (2015). Radiopaque strontium fluoroapatite glass-ceramics. Front. Bioeng. Biotechnol. 3:149. doi:10.3389/fbioe.2015.00149

Höland, W., and Vogel, W. (2013). "Machinable and phosphate glass-ceramics," in Introduction to Bioceramics, ed. L. L. Hench (London: Imperial College Press), 215-228.

Hopkins, R. H., Damon, D. H., Piotrowski, P., Walker, M. S., and Uphoff, J. H. (1971). Thermal properties of synthetic fluorapatite crystals. J. Appl. Phys. 42, 272-275. doi:10.1063/1.1659583

James, P. (1981). Nucleation in glass forming systems - a review. J. Am. Ceram. Soc. 60, 352-352.

Karageorgiou, V., and Kaplan, D. (2005). Porosity of 3D biomaterial scaffolds and osteogenesis. Biomaterials 26, 5474-5491. doi:10.1016/ j.biomaterials.2005.02.002

Kitsugi, T., Yamamuro, T., and Kokubo, T. (1989). Bonding behavior of a glassceramic containing apatite and wollastonite in segmental replacement of the rabbit tibia under load-bearing conditions. J. Bone Joint Surg. Am. 71A, 264-272. doi:10.2106/00004623-198971020-00014

Kitsugi, T., Yamamuro, T., and Kokubo, T. (1990). Analysis of A.W glass-ceramic surface by micro-beam X-ray-diffraction. J. Biomed. Mater. Res. 24, 259-273. doi:10.1002/jbm.820240211 
Kokubo, T. (2008). "Bioactive glass-ceramics," in Bioceramics and Their Clinical Applications, ed. T.Kokubo (Cambridge, England: Woodhead Publishing Limited), 288-289.

Kokubo, T., Ito, S., Sakka, S., and Yamamuro, T. (1986). Formation of a highstrength bioactive glass ceramic in the system $\mathrm{MgO}-\mathrm{CaO}-\mathrm{SiO}_{2}-\mathrm{P}_{2} \mathrm{O}_{5}$. J. Sci. Mater. 21, 536-540. doi:10.1007/BF01145520

Kokubo, T., Ito, S., Shigematsu, M., Sakka, S., and Yamamuro, T. (1985). Mechanical-properties of a new type of apatite-containing glass ceramic for prosthetic application. J. Sci. Mater. 20, 2001-2004. doi:10.1007/BF01112282

Kokubo, T., Ito, S., Shigematsu, M., Sanka, S., and Yamamuro, T. (1987). Fatigue and life-time of bioactive glass-ceramic A-W containing apatite and wollastonite. J. Sci. Mater. 22, 4067-4070. doi:10.1007/BF01133359

Kokubo, T., Kushitani, H., Ohtsuki, C., Sakka, S., and Yamamuro, T. (1992). Chemical-reaction of bioactive glass and glass-ceramics with a simulated bodyfluid. J. Mater. Sci. Mater. Med. 3, 79-83. doi:10.1007/BF00705272

Kokubo, T., Kushitani, H., Sakka, S., Kitsugi, T., and Yamamuro, T. (1990). Solutions able to reproduce in vivo surface-structure changes in bioactive glass-ceramic A-W. J. Biomed. Mater. Res. 24, 721-734. doi:10.1002/jbm.820240607

Kokubo, T., Shigematsu, M., Nagashima, Y., Tashiro, M., Nakamura, T., Yamamuro, T., et al. (1982). Apatite- and wollastonite-containg glass-ceramics for prosthetic application. Bull. Inst. Chem. Res. Kyoto Univ. 60, 260-268.

Kumar, V., and Gill, K. (2009). Aluminium neurotoxicity: neurobehavioural and oxidative aspects. Arch. Toxicol. 83, 965-978. doi:10.1007/s00204-009-0455-6

LeGeros, R. Z., Taheri, M. H., Quirolgico, G. B., and LeGeros, J. P. (1980). "Formation and stability of apatites: effects of some cationic substituents," in 2nd International Congress on Phosphorus Compounds (Boston, MA: IMPHOS (Paris)), 89-103.

McCubbin, F., and Nekvasil, H. (2008). Maskelynite-hosted apatite in the Chassigny meteorite: Insights into late-stage magmatic volatile evolution in martian magmas. Am. Mineral. 93, 676-684. doi:10.2138/am.2008.2558

McCubbin, F., Steele, A., Hauri, E., Nekvasil, H., Yamashita, S., and Hemley, R. (2010). Nominally hydrous magmatism on the Moon. Proc. Natl. Acad. Sci. U. S. A. 107, 11223-11228. doi:10.1073/pnas.1006677107

Montazerian, M., and Zanotto, E. D. (2016). History and trends of bioactive glass-ceramics. J. Biomed. Mater. Res. A. 104, 1231-1249. doi:10.1002/ jbm.a.35639

Nakamura, T., Yamamuro, T., Higashi, S., Kokubo, T., and Itoo, S. (1985). A new glass-ceramic for bone replacement: evaluation of its bonding to bone tissue. J. Biomed. Mater. Res. 19, 685-698. doi:10.1002/jbm.820190608

Neo, M., Nakamura, T., Ohtsuki, C., Kokubo, T., and Yamamuro, T. (1993). Apatite formation on three kinds of bioactive material at an early stage in vivo: a comparative study by transmission electron microscopy. J. Biomed. Mater. Res. 27, 999-1006. doi:10.1002/jbm.820270805

O’Donnell, M., Karpukhina, N., Calver, A., Law, R., Bubb, N., Stamboulis, A., et al. (2010). Real time neutron diffraction and solid state NMR of high strength apatite-mullite glass ceramic. J. Non Cryst. Solids 356, 2693-2698. doi:10.1016/ j.jnoncrysol.2010.08.038

Ohlmann, R. C., Steinbruegge, K. B., and Mazelsky, R. (1968). Spectroscopic and laser characteristics of neodymium-doped calcium fluorophosphate. Appl. Opt. 7, 905-914. doi:10.1364/AO.7.000905

Orlovskii, V., Komlev, V., and Barinov, S. (2002). Hydroxyapatite and hydroxyapatite-based ceramics. Inorg. Mater. 38, 973-984. doi:10.1023/A:1014029514176

Payne, S., Smith, L., Deloach, L., Kway, W., Tassano, J., and Krupke, W. (1994). Laser, optical, and thermomechanical properties of Yb-doped fluorapatite. IEEE J. Quant. Electron. 30, 170-179. doi:10.1109/3.272077

Pinckney, L. R., and Dejneka, M. J. (1998). Transparent Apatite Glass-Ceramics. WIPO, WO 1998043922 A1.

Piper, W. W., Kravitz, L. C., and Swank, R. K. (1965). Axially symmetric paramagnetic color centers in fluorapatite. Phys. Rev. 138, A1802-A1814. doi:10.1103/ PhysRev.138.A1802

Rafferty, A., Clifford, A., Hill, R., Wood, D., Samuneva, B., and DimitrovaLukacs, M. (2000a). Influence of fluorine content in apatite-mullite glassceramics. J. Am. Ceram. Soc. 83, 2833-2838. doi:10.1111/j.1151-2916.2000. tb01640.x

Rafferty, A., Hill, R., and Wood, D. (2000b). Amorphous phase separation of ionomer glasses. J. Sci. Mater. 35, 3863-3869. doi:10.1023/A:1004885531712

Rafferty, A., Hill, R., and Wood, D. (2003). An investigation into the amorphous phase separation characteristics of an ionomer glass series and a sodium-boro-silicate glass system. J. Sci. Mater. 38, 2311-2319. doi:10.1023/ A:1026240525763

Ramsden, A., and James, P. (1984a). The effects of amorphous phase-separation on crystal nucleation kinetics in $\mathrm{BaO}-\mathrm{SiO} 2$ glasses. 1. General survey. J. Sci. Mater. 19, 1406-1419. doi:10.1007/BF01026965

Ramsden, A., and James, P. (1984b). The effects of amorphous phaseseparation on crystal nucleation kinetics in $\mathrm{BaO}-\mathrm{SiO} 2$ glasses. 2. Isothermal heat-treatments at 700-degrees c. J. Sci. Mater. 19, 2894-2908. doi:10.1007/ BF01026965

Ranu, H. S. (1987). The thermal properties of human cortical bone: an in vitro study. Eng. Med. 16, 175-176. doi:10.1243/EMED_JOUR_1987_016_036_02

Reusche, E., Pilz, P., Oberascher, G., Lindner, B., Egensperger, R., Gloeckner, K., et al. (2001). Subacute fatal aluminum encephalopathy after reconstructive otoneurosurgery: a case report. Hum. Pathol. 32, 1136-1140. doi:10.1053/ hupa.2001.28251

Rodriguez, M., Felsenfeld, A. J., and Llach, F. (1990). Aluminum administration in the rat separately affects the osteoblast and bone mineralization. J. Bone Miner. Res. 5, 59-67. doi:10.1002/jbmr.5650050110

Sabareeswaran, A., Basu, B., Shenoy, S. J., Jaffer, Z., Saha, N., and Stamboulis, A. (2013). Early osseointegration of a strontium containing glass ceramic in a rabbit model. Biomaterials 34, 9278-9286. doi:10.1016/j.biomaterials.2013.08.070

Samuneva, B., Dimitrov, V., Kalimanova, S., Gattef, E., and Hill, R. (1998). Crystallization of gels in the apatite-mullite system. J. Solgel Sci. Technol. 13, 951-956. doi:10.1023/A:1008695812143

Segall, B., Ludwig, G. W., Woodbury, H. H., and Johnson, P. D. (1962). Electron spin resonance of a centre in calcium fluorophosphate. Phys. Rev. 128, 76-79. doi:10.1103/PhysRev.128.76

Siriphannon, P., Kameshima, Y., Yasumori, A., Okada, K., and Hayashi, S. (2000). Influence of preparation conditions on the microstructure and bioactivity of alpha-CaSiO(3) ceramics: formation of hydroxyapatite in simulated body fluid. J. Biomed. Mater. Res. 52, 30-39. doi:10.1002/ 1097-4636(200010)52:1<30::AID-JBM5>3.0.CO;2-Z

Soulet, S., Carpena, J., Chaumont, J., Kaitasov, O., Ruault, M., and Krupa, J. (2001). Simulation of the alpha-annealing effect in apatitic structures by He-ion irradiation: influence of the silicate/phosphate ratio and of the $\mathrm{OH}(-) / \mathrm{F}(-)$ substitution. Nucl. Instrum. Methods Phys. Res. B 184, 383-390. doi:10.1016/ S0168-583X(01)00764-9

Stamboulis, A., Hill, R., Calver, A., Bubb, N., Manuel, P., Nakamura, T., et al. (2006). Real time neutron diffraction studies of apatite glass ceramics. Bioceramics 18 (Pts 1 and 2), 309-311:309-312. doi:10.4028/www.scientific.net/KEM.309-311.309

Stamboulis, A., Hill, R., Law, R., Matsuya, S., Barbosa, M., Monteiro, F., et al. (2004). A MAS NMR study of the crystallisation process of apatite-mullite glass-ceramics. Bioceramics 16, 254-252. doi:10.4028/www.scientific.net/ KEM.254-256.99

Stanton, K., O’Flynn, K., Nakahara, S., Vanhumbeeck, J., Delucca, J., and Hooghan, B. (2009). Study of the interfacial reactions between a bioactive apatite-mullite glass-ceramic coating and titanium substrates using high angle annular dark field transmission electron microscopy. J. Mater. Sci. Mater. Med. 20, 851-857. doi:10.1007/s10856-008-3650-8

Stanton, K. T., and Hill, R. G. (2005). Crystallisation in apatite-mullite glassceramics as a function of fluorine content $\mathrm{C} 3$ - proceedings of the 14th international conference on crystal growth and the 12th international conference on vapor growth and epitaxy. J. Cryst. Growth 275, e2061-e2068. doi:10.1016/ j.jcrysgro.2004.11.266

Stanton, K. T., O’Flynn, K. P., Kiernan, S., Menuge, J., and Hill, R. (2010). Spherulitic crystallization of apatite-mullite glass-ceramics: mechanisms of formation and implications for fracture properties. J. Non-Cryst. Solids 356, 1802-1813. doi:10.1016/j.jnoncrysol.2010.07.006

Strnad, Z. (1992). Role of the glass phase in bioactive glass-ceramics. Biomaterials 13, 317-321. doi:10.1016/0142-9612(92)90056-T

Tomozawa, M. (1972). Liquid-phase separation and crystal nucleation in $\mathrm{Li}_{2} \mathrm{O}-\mathrm{SiO}_{2}$ glasses. Phys. Chem. Glasses 13, 161.

Tulyaganov, D. U. (2000). Phase equilibrium in the fluorapatite-anorthite-diopside system. J. Am. Ceram. Soc. 83, 3141-3146. doi:10.1111/j.1151-2916.2000. tb01695.x

Verberckmoes, S., De Broe, M., and D’Haese, P. (2003). Dose-dependent effects of strontium on osteoblast function and mineralization. Kidney Int. 64, 534-543. doi:10.1046/j.1523-1755.2003.00123.x 
Vogel, W., and Gerth, K. (1962). "Catalyzed crystallization in glass," in 63rd Anniversary of the American Ceramic Society Symposium on Nucleation and Crystallization of Glasses and Melts, ed. M. K.Reser (Toronto, Canada: American Ceramic Society), 11-22.

Vogel, W., Holand, W., Naumann, K., and Gummel, J. (1986). Development of machineable bioactive glass-ceramics for medical uses. J. Non-Cryst. Solids 80, 34-51.

Weber, W. (1993). Alpha-decay-induced amorphization in complex silicate structures. J. Am. Ceram. Soc. 76, 1729-1738. doi:10.1111/j.1151-2916.1993. tb06641.x

Weber, W. J., Turcotte, R. P., Bunnell, L. R., Roberts, F. P., and Westsik, J. H. Jr. (1979). "Radiation Effects in Vitreous and Devitrified Simulated Waste Glass," in Ceramics in Nuclear Waste Management, eds T. D. Chikalla and J. E. Mendel (Virginia: National Technical Information Service, Springfield), 294-299.

White, T., Ferraris, C., Kim, J., Madhavi, S., Ferraris, G., and Merlino, S. (2005). Apatite - an adaptive framework structure. Micro Mesoporous Mineral Phases 57, 307-401. doi:10.2138/rmg.2005.57.10

Wood, D., and Hill, R. (1991). Glass ceramic approach to controlling the properties of a glass-ionomer bone cement. Biomaterials 12, 164-170. doi:10.1016/0142-9612(91)90195-G

Zanotto, E. (2010). A bright future for glass-ceramics. Am. Ceram. Soc. Bull. 89, $19-27$.

Zanotto, E., James, P., and Craievich, A. (1986). The effects of amorphous phase-separation on crystal nucleation kinetics in $\mathrm{BaO}-\mathrm{SiO}_{2}$ glasses. 3 . Isothermal treatments at $718^{\circ} \mathrm{C}$ to $760^{\circ} \mathrm{C}$ - small-angle X-ray-scattering results. J. Sci. Mater. 21, 3050-3064. doi:10.1007/BF00553336
Zeng, Q., and Stebbins, J. (2000). Fluoride sites in aluminosilicate glasses: high-resolution F-19 NMR results. Am. Mineral. 85, 863-867. doi:10.2138/ am-2000-5-630

Zhang, S., Huang, J., Chen, Y., Gong, X., Lin, Y., Luo, Z., et al. (2012). Preparation and spectral properties of $\mathrm{Nd} 3+$-doped transparent glass ceramic containing Ca-5(PO4)(3)F nanocrystals. J. Non Cryst. Solids 358, 2835-2840. doi:10.1016/ j.jnoncrysol.2012.07.005

Zhang, S., Huang, J., Chen, Y., Gong, X., Lin, Y., Luo, Z., et al. (2013a). Site-selective excitation and emission of Eu3 + -doped transparent glass ceramic containing Ca-5(PO4)(3)F nanocrystals. Opt. Mater. Express 3, 868-874. doi:10.1364/ OME.3.000868

Zhang, S., Huang, J., Chen, Y., Gong, X., Lin, Y., Luo, Z., et al. (2013b). Spectroscopic properties of $\mathrm{Nd} 3$ + -doped transparent glass ceramic containing Sr-5(PO4)(3)F nanocrystals. J. Non Cryst. Solids 366, 35-41. doi:10.1016/ j.jnoncrysol.2013.01.048

Conflict of Interest Statement: The authors declare that the research was conducted in the absence of any commercial or financial relationships that could be construed as a potential conflict of interest.

Copyright (C) 2017 Duminis, Shahid and Hill. This is an open-access article distributed under the terms of the Creative Commons Attribution License (CC BY). The use, distribution or reproduction in other forums is permitted, provided the original author(s) or licensor are credited and that the original publication in this journal is cited, in accordance with accepted academic practice. No use, distribution or reproduction is permitted which does not comply with these terms. 